\title{
Quantifying occurrence of deformation bands in sandstone as a function of structural and petrophysical factors and their impact on reservoir quality: an example from outcrop analog of Productive Series (Pliocene), South Caspian Basin
}

\author{
Shahriyar Alkhasli ${ }^{1}$. Gasham Zeynalov ${ }^{1,2}$. Aydin Shahtakhtinskiy ${ }^{1,3}$
}

Received: 28 September 2021 / Accepted: 24 December 2021 / Published online: 7 January 2022

(c) The Author(s) 2022

\begin{abstract}
Deformation bands (DB) are known to influence porosity and permeability in sandstones. This study aims to predict the occurrence of DB and to quantify their impact on reservoir properties based on field measurements in the steeply dipping limb of a kilometer-scale fold in Yasamal Valley, western South Caspian Basin. An integrated approach of characterizing bands and their effect on reservoir properties included measurements of natural gamma radioactivity and permeability using portable tools, along with bed dip and the count of DB across distinct facies. A set of core analyses was performed on outcrop plugs with and without bands to estimate the alteration of rock properties at the pore scale. Interpretation of outcrop gamma-ray data indicates the absence of bands in Balakhany sandstones containing shale volume greater than $18 \%$ for unconsolidated and $32 \%$ for calcite-rich facies. A high amount of calcite cement appears to increase the number of DB. A poor, positive trend between bed dip and DB concentration was identified. We show that net to gross, defined as the thickness fraction of sandstone bound by mudstones, is among the parameters controlling the occurrence of bands. Samples containing a single DB show a 33\% and 3\% decrease in permeability and porosity, respectively, relative to the host rock. We reveal a new set of lithological and petrophysical factors influencing DB occurrence. This study offers a direct tool that can be applied in subsurface reservoir analogs to predict the occurrence and concentration of DB and estimate their influence on rock properties.
\end{abstract}

Keywords Deformation band $\cdot$ Sandstone $\cdot$ Structural control $\cdot$ Shale volume $\cdot$ Porosity $\cdot$ Permeability $\cdot$ Yasamal Valley

\section{Introduction}

Fluid flow in reservoir rocks can be heavily influenced by naturally occurring, deformation-related features depending on their type and distribution (Tsang and Neretnieks 1998; Rotevatn et al. 2009; Zhou et al. 2014; Zuluaga et al. 2016). The current study is concerned with deformation bands (DB) - tabular structures forming in brittle porous granular media that were extensively investigated by several authors.

Shahriyar Alkhasli

shahriyar.alkhasli@khazar.org

1 eiLink R\&D Center, Khazar University, AZ1009 Baku, Azerbaijan

2 Present Address: Department of Petroleum Engineering, Baku Higher Oil School, AZ1025 Baku, Azerbaijan

3 Present Address: Department of Earth and Atmospheric Sciences, University of Houston, Houston, TX 77204, USA
One of the pioneering studies about DB was done in Entrada and Navajo sandstones by Aydin (1978), who recognized such structures as small faults with displacements ranging from a few millimeters to a few centimeters, which is below seismic resolution and cannot be readily detected by conventional well logs. There are only few studies examining formation of deformation bands and their influence on rock properties in subsurface fields (Wilkins et al. 2020; Liu et al. 2021). Therefore, more efforts were put to characterize them from outcrop analogs (e.g., Sanderson 2016; Gambino et al. 2019). Since deformation bands are known to influence the fluid flow in porous media, attempts were made to predict their occurrence in a rock volume (Das et al. 2011; Robert et al. 2019; Wu et al. 2020) and quantify their impact at pore (Atilla and Ahmadov 2009; Das et al. 2013) and reservoir (Botter et al. 2016; Wilson et al. 2021; Pourmalek et al. 2021) scales. 
In the present-day literature, deformation bands are known as strain localization features forming in highly porous sandstones (e.g., Shipton and Cowie 2001; Fossen et al. 2007; Elphick et al. 2021) and are classified into several types (disaggregation bands, phyllosilicate bands, cataclastic bands, and solution and cementation bands) based on deformation mechanisms, leading to different petrophysical properties (Fossen et al. 2007). This depends on the kinematic and mechanic response of host rock grains to applied dynamical processes, resulting in grain reorganization mainly by sliding, rotation, and/or fracturing. Based on a numerical study, Xiong et al. (2021) suggested that porosity and pore structure are the primary controls in the evolution of failure mode with confining pressure. The type of deformation bands, on the other hand, is controlled by intrinsic rock properties, including mineralogy, grain roundness, sorting, etc. (Fossen et al. 2017). Based on mechanical data and microstructural observations, Tembe et al. (2008) demonstrated that deformation bands are characterized to be the dominant mechanism of rock failure in arkosic sandstones in the transitional regime from brittle faulting to cataclastic flow. Beke et al. (2019) suggested that the evolution of deformation bands is primarily controlled by burial history: DB gradually change from disaggregation to cataclastic bands with increasing burial depth. Fossen et al. (2017) reviewed that the tectonic regime plays a dominant role in the distribution and organization of DB in porous sandstone. That is, in contractional tectonic settings, DB are widely distributed in space in response to the higher mean stress applied, while sandstones exposed to extensional tectonics tend to have localized behavior of DB distribution. It should be noted that primary lithologic heterogeneities and presence of faults influence the distribution of deformation bands (Soliva et al. 2016; Torabi et al. 2021) but do not control its general trend.

An extensive, qualitative analysis of direct and indirect factors controlling the formation of deformation bands was done by Fossen et al. (2017). Many variables complicate the quantitative prediction of deformation bands at the field scale, and differentiating their contribution often becomes a challenge. Nevertheless, Zuluaga et al. (2014) and Fossen et al. (2017) observed an increasing trend in the number of DB per meter with an increasing bed dip in fault-propagation folds, which can be considered as a representation of strain.

Millimeter-to-centimeter thicknesses of deformation bands restrict direct measurements of porosity and permeability inside individual bands using Routine Core Analysis (RCAL) or Mercury Injection Capillary Pressure (MICP) experiments, unless they cluster into a thick DB zone [5-10 cm (2-4 in.)] that can be sampled as a single plug for standard measurements. Hence, alternative, indirect calculation methods are required for single bands, such as one- and two-point spatial correlation functions (Torabi et al. 2008),
Lattice-Boltzmann modeling (Keehm et al. 2006), and other techniques applied to a binary image [derived from thin sections, computed tomography (CT), scanning electron microscopy (SEM), etc.] of rocks containing deformation bands.

The impact of deformation bands on fluid flow can be considered as a function of their kinematics and petrophysical properties, which control cataclasis intensity. Ballas et al. (2015) summarized data from 31 studies and revealed that the permeability reduction in an individual deformation band ranges from zero to six orders of magnitude compared to the host rock. Fossen and Bale (2007) evaluated the reduction in flow efficiency based on the differential form of steady-state Darcy equation and concluded that the permeability difference between the host rock and the deformation band should be higher than four orders of magnitude to have a significant effect on fluid flow. Romano et al. (2020) and Romano et al. (2021) showed via core-scale fluid flow simulations that deformation bands can act as strong capillary barriers and cause fluid compartmentalization in sandstones. Numerical simulations were also performed for carbonate (Rotevatn et al. 2016) and siliciclastic (Matthai et al. 1998; Sternlof et al. 2006; Zuluaga et al. 2016; Awdal et al. 2020) reservoirs to examine the influence of deformation bands on total recovery with respect to their permeability contrast with the host rock. Rotevatn et al. (2009) concluded that deformation bands may have both positive and negative effects on sweeping efficiency, depending on the permeability contrast. While Rotevatn et al. (2016) showed that the reduction in permeability in deformation bands reduces the sweep efficiency, Zuluaga et al. (2016) observed, on the contrary, that there is an increase in the total recovery factor when the permeability of deformation bands drops. Different outcomes of production performance obtained in these works outline the state of the art in the understanding of DB characteristics and highlight the complexity and the importance of the problem.

In this paper, we deal with cataclastic bands (Nogueira et al. 2021; Silva de Souza et al. 2021) widely distributed within the contractional, steeply dipping flank of a 5-km (3.1 mi.)-long anticline in the Apsheron Peninsula, Azerbaijan, where porosity and permeability reduction occurs through some degree of granulation (cataclasis) and compaction of host rock grains. The aim of the study is to provide a tool that can be used in reservoir modeling to predict conditions of DB occurrence in sandstones and to evaluate rock properties in deformed areas of the hydrocarbon fields in Azerbaijan based on outcrop and laboratory measurements. The study was inspired by the need in the industry to address the quantitative characterization of degradation of rock properties at the reservoir scale that can find its reflection in the subsurface models. We want to determine (1) how deformation bands are formed and distributed along and across the 
steeply dipping limb of an anticline fold and (2) how much they alter porosity and permeability at the field and pore scales.

To address these questions, the scope of the research included an examination of correlations between the bed dip and the number of DB observed along and across steeply dipping and overturned parts of the plunging anticline. Similarly, the effect of mineralogical composition (clay content), which is believed to control the elastic properties of rocks (Bai 2016), was investigated through estimation of the shale volume of sandstones derived from field measurements of natural gamma radioactivity. Many previous studies focus on qualitative-and less frequently quantitative-microstructural analyses of deformation bands based on photomicrographs of thin sections (e.g., Antonellini et al. 1994; Torabi and Fossen 2009), which are less available in the industry due to a limited number of core samples as opposed to the extensively used, continuous well log data. Hence, the motivation in this study was to implement gamma-ray (GR) logs for direct application purposes in large-scale reservoirs. Additionally, we hypothesize that mudstones that sandwich a sandstone layer may potentially act as stress absorbers and influence the concentration of deformation bands in the study area represented by layer-cake formations (alternating sandstones and mudstones). This approach was introduced in this study through a novel net-to-gross analysis, which can also be readily applied to well logs.

Finally, the influence of deformation bands on reservoir properties was quantified through abundant measurements of permeability on the outcrop samples in the laboratory and on the surface of the exposed rocks using a portable permeameter in the field. The reduction in initial rock porosity and permeability caused by a single deformation band was determined at the micro scale. The magnitude of reduction in the reservoir properties was then examined against mineralogical composition and facies type.

\section{Geological setting}

\section{Regional geology}

Azerbaijan is located in the Caucasus region of the Alpine-Himalayan fold belt, and its main geo-structural elements are the South Caspian Basin (SCB) and the Kura Basin in the eastern and western parts, respectively (Fig. 1a). The Kura intermountain basin extends between the Greater and Lesser Caucasus mountain systems from the east of Georgia to the west coast of the Caspian Sea. This basin was shaped by multi-phase active tectonism accompanied by the collision, accretion, and rotation of the plates of Eastern European Platform and Arabian plate during the Eocene-Pliocene time (Zonenshain and Pichon 1986; Granath and Baganz 1996; Jackson et al. 2002; Brunet et al. 2003; Nemcok et al. 2011). Compared to the SCB, the Kura intermountain basin has a more structurally complicated history with the occurrence of different types of volcanogenic processes, sharp facial variations, and stratigraphically irregular oil and gas saturation in volcanoclastic, carbonate and siliciclastic

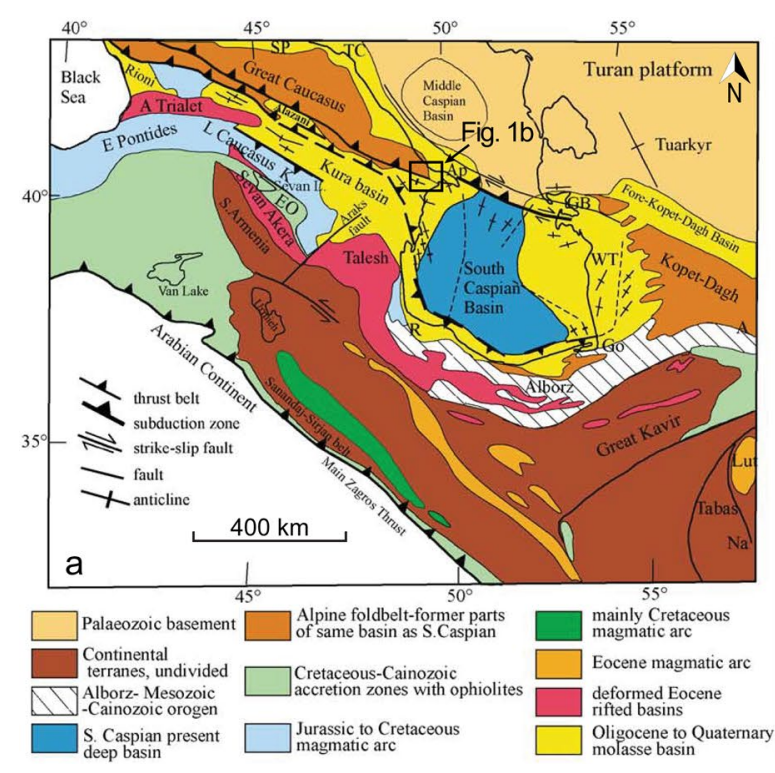

Fig. 1 a Regional geological map of the main tectonic units of the South Caspian region (modified after Brunet et al. 2003). b Geological map of the eastern Greater Caucasus, the northeastern Kura basin,

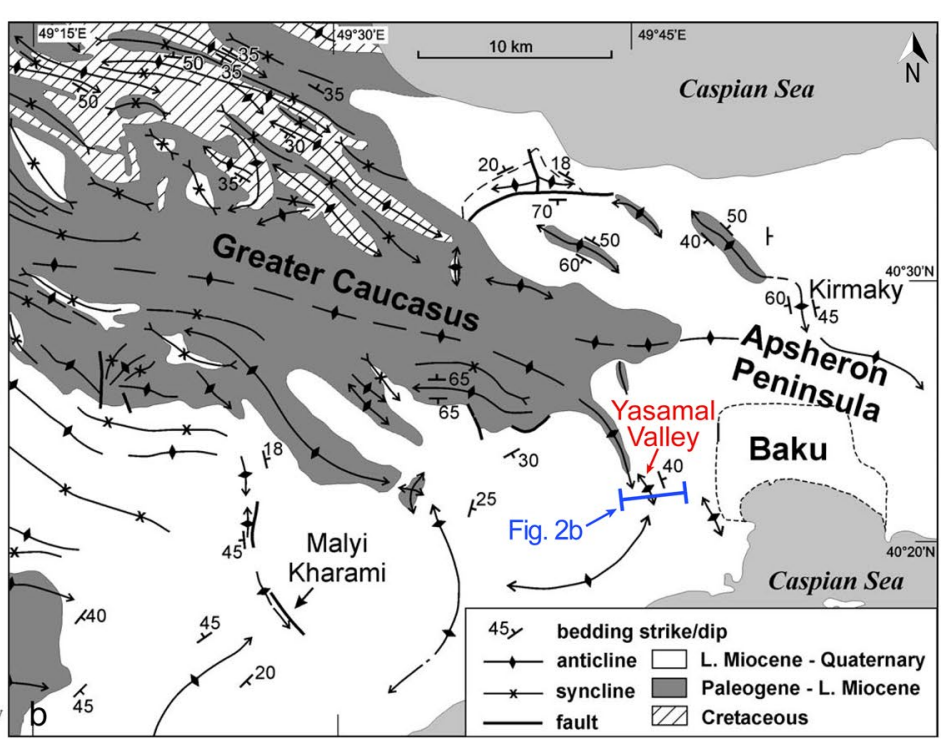

and the western Apsheron Peninsula, showing the location of the studied anticline in Yasamal Valley (modified after Allen et al. 2003). Map location is shown with the black rectangle in (a) 
sedimentary rocks. Only the eastern part of the basin, named the Lower Kura sub-basin, is similar to the SCB in terms of its geologic structure and tectonic evolution, both being characterized by high sedimentation rates in the relatively recent Pliocene-Quaternary time (Abdullayev et al. 2018).

The Productive Series (Lower Pliocene), considered to be the main reservoir rock in the South Caspian and nearby Kura basins, was accumulated by the Paleo-Volga, Paleo-Amu Darya, and Paleo-Kura rivers after the isolation of the Caspian Lake from the world ocean in the early Pliocene (Jones and Simmons 1996; Reynolds et al. 1998; Aliyeva 2005; Green et al. 2009). In the Kura basin, the thickness of mud-rich, argillaceous sediments of the Productive Series brought by the paleo-Kura river reaches more than $2 \mathrm{~km}$. In contrast, the giant paleo-Volga river has brought the sand-rich sediments of the Productive Series that increase in thickness and reservoir quality toward the Apsheron Peninsula of the SCB.

Many outcrops exist in the Apsheron Peninsula that contain both the structural and sedimentological elements described above. The exposed rocks display plunging anticlines manifested by mixtures of thrust, strike-slip, and normal faults in different parts of the structure, where strain during folding is accommodated in a similar manner to the offshore fields (Allen et al. 2003).

\section{Outcrop analog: Yasamal Valley}

Yasamal Valley, represented by a plunging anticline, has the most favorable conditions to study deformation bands on the outcropping Productive Series and was chosen to be the main area of investigation for this study. The outcrops of Yasamal Valley are good structural and sedimentological analogs to the offshore fields of the SCB: they are steeply dipping (Allen et al. 2003), abundant in deformation bands (Souque et al. 2010), and rich in clean, unconsolidated sandstones of similar properties (Reynolds et al. 1998; Hinds et al. 2004). Sanderson (2016) showed qualitatively the presence of deformation bands in Yasamal Valley outcrops in similar intensities and orientations to DB observed in the cores from the Productive Series sandstones in the offshore ACG field, Azerbaijan.

The Yasamal anticline (also known as Shubani) is located in the Apsheron Peninsula to the north-west of the SCB (Fig. 1b) and was formed as a result of folding during the late Pliocene (Gurevich and Chilingar 1995). It is a four-way dipping anticline with well-pronounced north/south pericline areas and flanks dipping in the east and west directions. The structure is complicated by three longitudinal faults at the crest—one of which is a thrust fault (Alizadeh et al. 1966; Allen et al. 2003), causing the steepening of dips in the east limb of the anticline-and by series of east-west-oriented normal and reverse faults (Fig. 2a). The structure is partly asymmetric, with the west

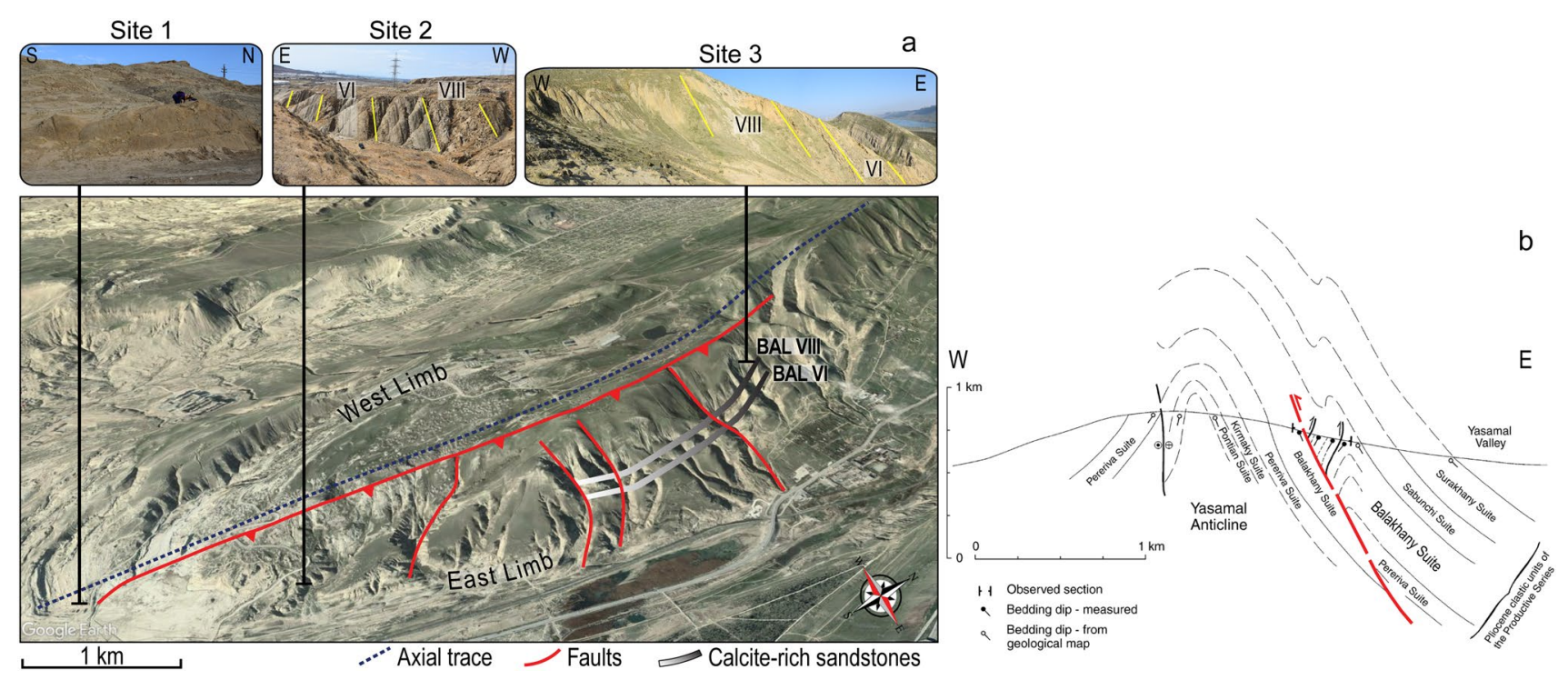

Fig. 2 a Google Earth image of the Yasamal (Shubani) anticline, showing the locations of measured sections (Sites 1, 2, 3), faults, and distribution of calcite-rich layers (Balakhany [BAL] VIII and VI) observed in this study. The long fault near the crest is the main thrust that follows close to the slightly curved anticline axis. Elevation is vertically exaggerated by a factor of two. The yellow lines in site images represent subunit boundaries. b Interpreted geological cross section of the Yasamal anticline, showing west dipping thrusts on the hanging wall of the main thrust fault (red) at the east limb and an approximated reconstruction of the crest and hinges (modified after Allen et al. 2003). Cross-section location is shown in Fig. 1b 
limb dipping at around 40 degrees, and segments of the east limb outcrops dipping at a near-vertical position. The overturned layers of the east limb (Fig. 3) are observed along the entire flank and interpreted as west dipping thrusts within the hanging wall of the main thrust (Allen et al. 2003) (Fig. 2b).

The exposed stratigraphic succession in Yasamal Valley consists of the Upper Productive Series (Fig. 4a) and has been under investigation for the last few decades; various opinions exist on the subdivision of its units. The alternating successions of sandstone- and mudstone-dominated facies of the Balakhany Suite characterize repeated proximal and distal fluvial-deltaic paleoenvironments during high-frequency base-level fluctuations (Kroonenberg et al. 2005), which resulted in layer-cake reservoirs, comprised of channel and sheet sandstones. The assignment of subunits in our study was based on the vertical changes in the mutual proportion of sandstone and mudstone layers and was assisted with GR logs, depicted in Fig. 4b (the collection procedure of the outcrop GR data is described in the following methodology chapter).

Outcrop observations reveal two well-exposed sandstone subunits: the thicker and coarser-grained sandstones of Balakhany VIII, and the thinner-bedded and finer-grained sandstones of Balakhany VI formations (inset images in Figs. 2a, 3). These sandstone-prone units are deposited during periods of increased fluvial-deltaic discharge and sediment supply to the basin. Sand-prone settings mainly consist of amalgamated and sheet sandstones. Mudstone-rich settings, comprised of Balakhany $\mathrm{V}$, VII, and IX intervals, are dominated by alluvial plain and lacustrine facies.

\section{Methods}

To characterize the relationship of deformation bands characteristics with reservoir properties and other influencing factors (bed geometry, mineralogy, net to gross, etc.), a set of portable tools, such as Gamma Ray and Permeameter, in the field and a complex of laboratory measurements were used.

\section{Field measurements}

The fieldwork was performed in three locations along the fold: the south pericline (Site 1), and the southern (Site 2) and northern (Site 3) parts of the east limb (Fig. 2a), where deformation bands are widely distributed. Sections were measured with $30 \mathrm{~cm}(1 \mathrm{ft})$ increment, where for each point lithological description and measurements of gamma-ray, permeability, and structural elements were made.

\section{(1) Lithological and structural descriptions in measured sections}

A detailed description of facies was made both across the stratigraphy, covering Balakhany IX to $\mathrm{X}$ formations, and laterally along individual sandstone units to allow the analysis of the impact of DB characteristics on the whole sequence, as well as on a single reservoir unit. For each measured point, deformation bands were counted using the scanline approach along $1 \mathrm{~m}[3.28 \mathrm{ft}]$ sections perpendicular to the measurements path. Orientations (strike and dip) of individual layers were measured using a Brunton compass to investigate the quantity of DB as a function of bed geometry, particularly steepness.

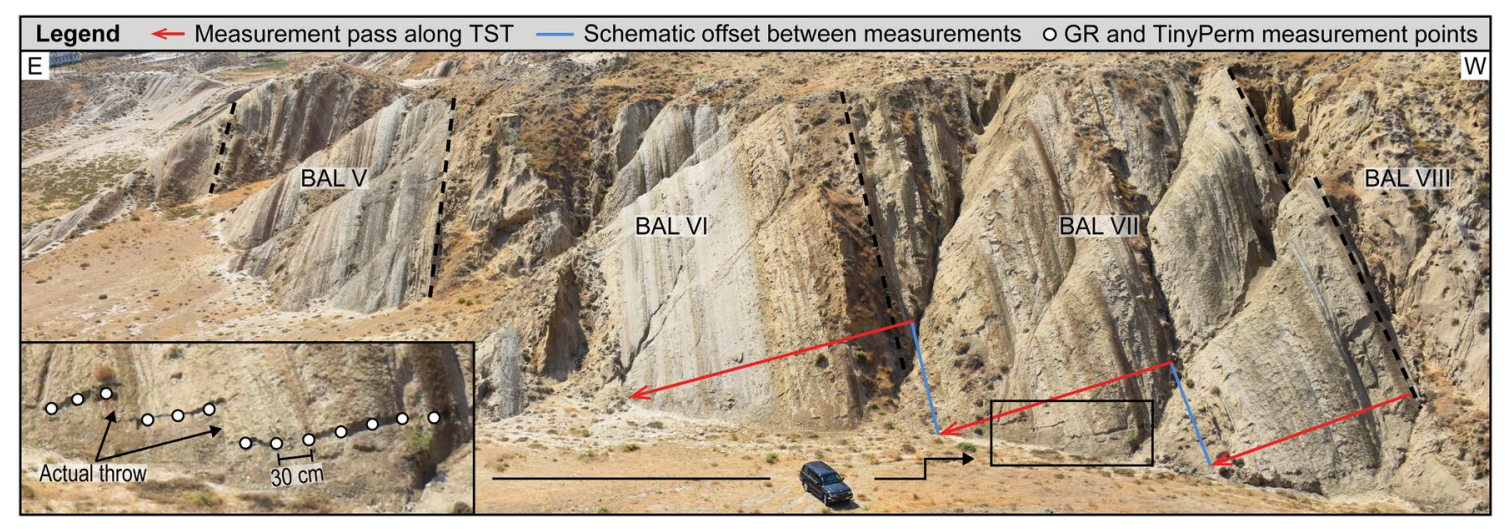

Fig. 3 Outcrop of slightly overturned layers in the east limb of the Yasamal anticline, showing an example of schematic logging along the true stratigraphic thickness (TST) of Balakhany (BAL) subunits at Site 2 from Fig. 2a. The red arrows show the direction of measurements along the TST of the layers, and the blue lines display the schematic throw between measurements along the layer contacts. The black box in the lower left corner is a close-up example of the actual measurement path, where real throws are much smaller than shown in the schematic. White circles represent example locations of gammaray (GR) measurements with $30 \mathrm{~cm}$ (11.8 in.) increment. TinyPerm II measurements were made only in sandstones at the same positions as GR points 

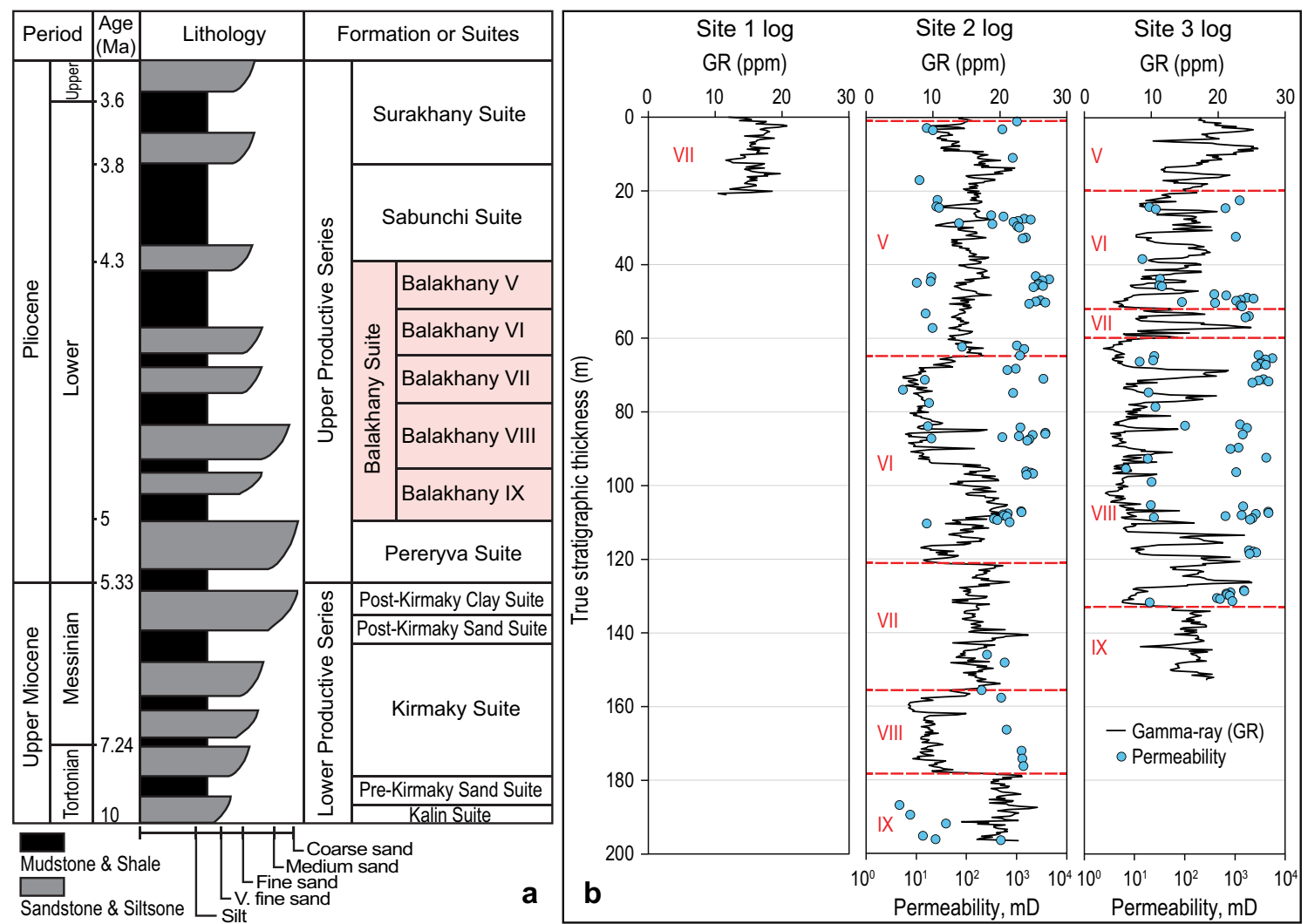

Fig. 4 a Generalized stratigraphic column of the Productive Series at Yasamal Valley summarizing the vertical changes in lithology through the Series (modified after Devlin et al. 1999). The Balakhany Suite (shaded in red) is the main interest in this study. b Gamma-ray (GR) $\operatorname{logs}$ of the Balakhany Suite subunits (IX-V) measured with

\section{(2) Gamma-ray measurements and calculation of shale vol-} ume

Portable GR tool (MGS-150) was used for stationary measurements of the natural radioactivity of the Balakhany Suite (Upper Productive Series) rocks to construct a comprehensive GR log with $30 \mathrm{~cm}(1 \mathrm{ft})$ increment along the true stratigraphic thickness (TST) of the outcropping layers, as illustrated schematically by arrows and circles in Fig. 3 . To estimate clay content at the bed scale and relate it to the distribution of deformation bands in the field, shale volume $\left(\mathrm{V}_{\text {shale }}\right)$ was calculated from outcrop GR logs using Steiber's 1970 empirical equation (Asquith and Krygowski 2004):

$$
\begin{aligned}
& V_{\text {shale }}=\frac{I_{\mathrm{GR}}}{3-2 \times I_{\mathrm{GR}}} \\
& I_{\mathrm{GR}}=\frac{\mathrm{GR}_{\log }-\mathrm{GR}_{\text {min }}}{\mathrm{GR}_{\max }-\mathrm{GR}_{\text {min }}}
\end{aligned}
$$

$30 \mathrm{~cm}$ (11.8 in.) increment (see Fig. 3) in three sections at the Yasamal anticline (Sites 1, 2, and 3 in Fig. 2a), with corresponding TinyPerm II measurements of permeability (converted to standard plug values) in sandstones

where $\mathrm{GR}_{\log }$ is the gamma-ray reading of a given point, and $\mathrm{GR}_{\min }$ and $\mathrm{GR}_{\max }$ are the minimum and maximum gamma-ray values in the measured interval.

It is important to note that shale volume derived using this approach is different from the quantification of clay and phyllosilicate content from petrographic images at the micro-scale (e.g., Knipe et al. 1997) in that it represents centimeter-scale measurements as adopted from the wireline logs used in the industry.

\section{(3) Sandstone net-to-gross calculation}

The influence of the strongly layered, heterogeneous rock system of the Balakhany Suite on the conditions of deformation band formation was of particular interest. To assess the effect of bounding mudstone layers on the distribution of deformation bands within an encased sandstone body, we introduced a simple approach called "sandwich net to gross (NTG)" (see Fig. 5), which is defined as: 


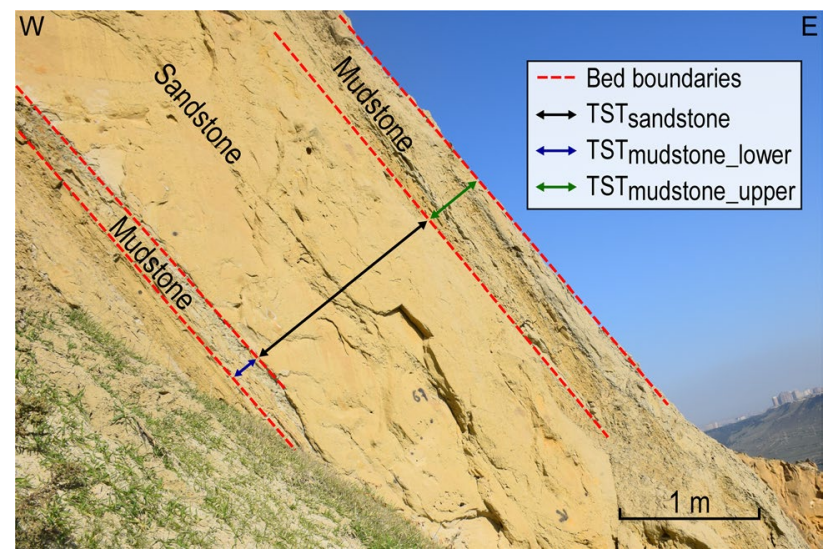

Fig. 5 Schematic representation of "sandwich net to gross (NTG)," showing a sandstone unit bound by mudstone layers in Balakhany VIII subunit at Site 3 from Fig. 2a. Refer to text for a detailed explanation

Sandwich NTG $=\frac{\mathrm{TST}_{\text {sandstone }}}{\mathrm{TST}_{\text {sandstone }}+\mathrm{TST}_{\text {mudstone_upper }}+\mathrm{TST}_{\text {mudstone_lower }}}$

where $\mathrm{TST}_{\text {sandstone }}$ is the true stratigraphic thickness of a sandstone layer and $\mathrm{TST}_{\text {mudstone_upper }}$ and $\mathrm{TST}_{\text {mudstone_lower }}$ represent the TST of the overlying and underlying mudstone beds, respectively.

\section{(4) Permeability measurements in the field}

A portable permeameter (Tiny Perm II) was used to measure the air permeability of sandstones at the same locations as the stationary GR measurement points (see white circles in Fig. 3) and analyze the impact of deformation bands on permeability at the field scale. An average of three measurements was recorded at each point and converted to a plug-equivalent value (divided by 1.8 [Fossen and Torabi 2011]). These permeability values are shown in Fig. 4b (blue points).

\section{Laboratory measurements}

Factors controlling the rock properties in deformed areas cannot be fully evaluated and described by the field measurements (GR and permeameter) alone. Therefore, a composite analysis of thin section petrography and laboratory tests, such as RCAL, SEM, X-Ray Diffraction (XRD), and CT, was carried out to proclaim the impact of those factors at the pore scale. Sister-plugs with and without a deformation band were sampled within a short distance (1-2 cm [0.4-0.8 in.]) from each other to minimize any dissimilarity associated with different sedimentological structures or features. Due to the friable nature of the Yasamal Valley sandstones, the plugs were extracted in the direction of horizontal permeability (drilling directly into the layer). Figure 6 shows plugs of the two main sandstone facies with DB. The identification of minerals was made via XRD and SEM measurements. The former provides fractional content of minerals, while the latter displays the spatial distribution of oxides and their percentages in the sample. Porosity and permeability of the plugs were measured using helium porosimeter and air permeameter at confining pressure (400 psi $\left.\left[28.1 \mathrm{~kg} / \mathrm{cm}^{2}\right]\right)$.

Although there are sophisticated numerical modeling techniques for estimation of the permeability of a single DB (see the Introduction section for details), within the scope of our study, we used a simple harmonic averaging methodology of serial beds (Ahmed 2001), one of which was taken as a deformation band (Fig. 6a). The analytical equation, used to derive DB permeability, is defined as:
Fig. 6 Examples of sandstone plugs with a deformation band. a Calcite-rich sandstone plug with setting parameters for calculating the permeability of a single deformation band using the harmonic average method (see Eq. 3). b Unconsolidated sandstone plug. The plugs are $4.5 \mathrm{~cm}$ (1.77 in.) in length and $3.7 \mathrm{~cm}$ (1.46 in.) in diameter. The deformation bands in the samples are contoured by red dashed lines
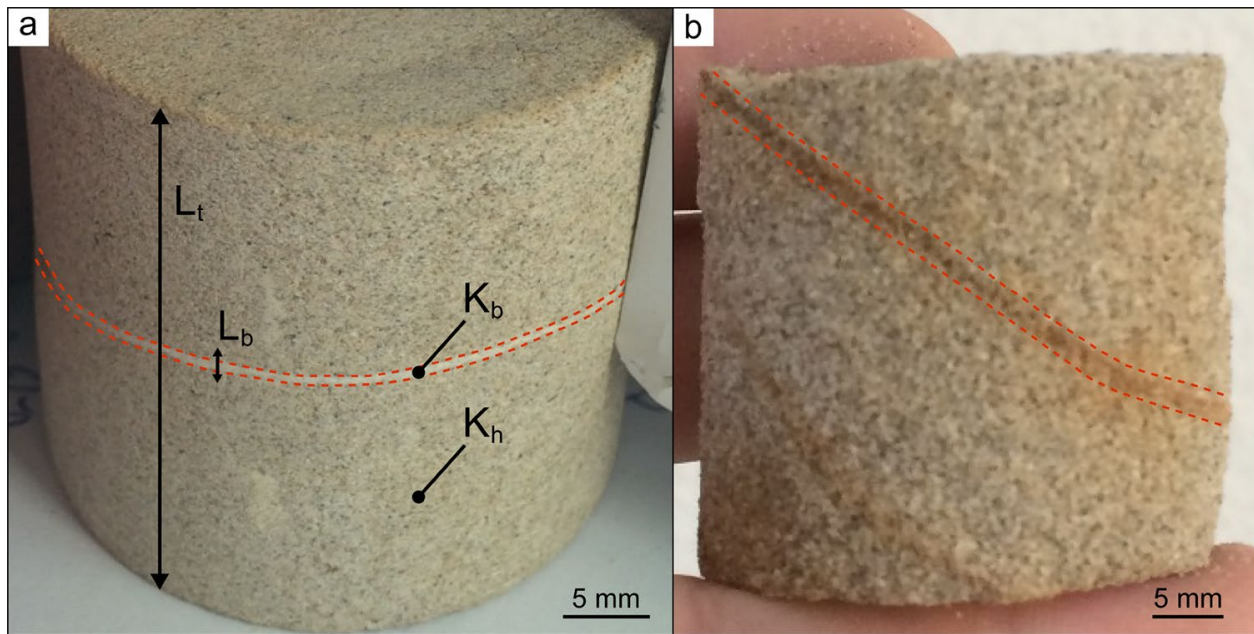
$K_{\mathrm{av}}=\frac{L_{t}}{\frac{L_{b}}{K_{b}}+\frac{\left(L_{t}-L_{b}\right)}{K_{h}}}$

where $K_{\mathrm{av}}$ is the average permeability of a plug with a deformation band, $L_{\mathrm{t}}$ is the total length of the plug, $L_{\mathrm{b}}$ is the width of the deformation band inside the plug (inferred from $\mathrm{CT}$ scans), $K_{\mathrm{h}}$ is the host rock (matrix) permeability (sister plug without a deformation band), and $\mathrm{K}_{\mathrm{b}}$ is the deformation band permeability.

\section{Description of the host rock and deformation bands}

Sandstones observed in the Yasamal Valley outcrops can be classified into two main types: (1) unconsolidated, relatively clean and (2) consolidated, calcite-rich. While the first type is observed across the entire structure, calcite-rich sandstones are locally distributed in the east limb (in the form of calcite concretions and cemented beds), extending from its northern end about $2 \mathrm{~km}$ (1.24 mi.) toward the south (refer to Fig. 2a). XRD data show that these facies have a sharp contrast in mineralogical composition (Fig. 7). While the percentage of calcite in unconsolidated sandstones varies between 10 and $20 \%$, it reaches $40 \%$ to $50 \%$ in calcite-rich sandstones. Analysis of the thin section and SEM images show that the Balakhany Suite sandstones are mostly fine to very fine grained and generally moderately sorted (Fig. 8).

Deformation bands in Yasamal valley sandstones range in lengths from centimeter scale in individual bands to meter scale in clusters of bands (Fig. 9). The calcite-rich sandstones are more abundant in deformation bands, displaying chaotic distribution patterns, compared to the less dense DB networks with a preferential orientation in unconsolidated sandstone beds (Fig. 9). Tiny offsets were observed in a few

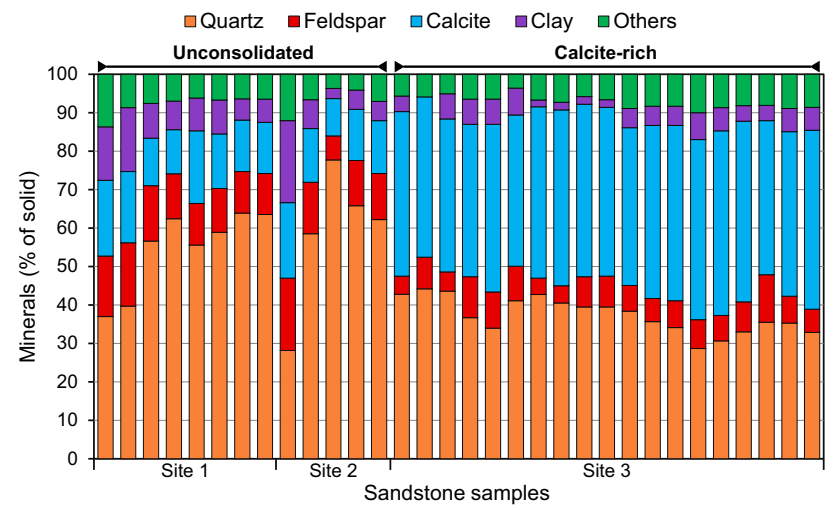

Fig. 7 Mineralogical composition of the unconsolidated, relatively clean, and consolidated, calcite-rich sandstones based on X-Ray Diffraction data from 32 samples collected in the three sites. In Site 3, only calcite-rich sandstones were sampled. Site locations are shown in Fig. 2a

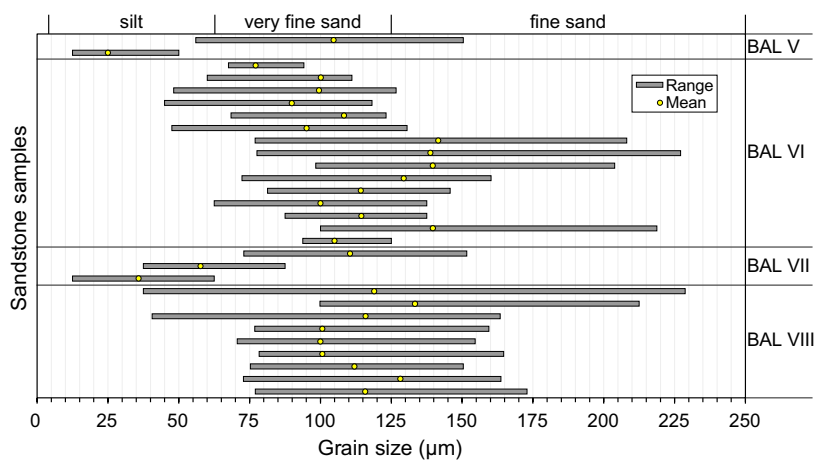

Fig. 8 Grain-size ranges of the Balakhany (BAL) Suite sandstone samples derived from thin sections and scanning electron microscopy images, classified into mainly fine- and very fine-grained sands (using the classification scheme by Wentworth 1922)

cases where bands cross-cut lamination or each other. From a kinematic point of view, the studied bands can be classified as shear-enhanced compaction bands, as seen from their inclinations relative to bed boundaries (Fig. 9a).

The photomicrographs of the thin sections display cataclastic bands with various degrees of cataclasis and high compaction in both sandstone facies. For example, samples one (Fig. 10a, b) and two (Fig. 10c, d) show more cataclasis than sample three (Fig. 10e, f), witnessed by the smaller grains inside the bands in contrast to the surrounding grains of the host rock. Unconsolidated sandstones (sample one) have finer and angular to subangular grains, while the grains in calcite-rich facies are subangular to poorly rounded (samples two and three). The latter samples also have a relatively uniform distribution of grain sizes within the bands. Sample one has the highest clay content (16.6\% from XRD data in Table 1) among unconsolidated sandstones with deformation bands.

\section{Formation conditions of deformation bands}

Distribution of deformation bands across the plunging anticline in Yasamal Valley varies significantly and depends on the lithology of the formations and bed geometry.

\section{Lithologic and mineralogic control}

Processing and subsequent interpretation and analysis of GR logs and deformation bands data yielded that no bands (or other deformation structures) are observed for any bed dips in various locations of the Yasamal Valley outcrops, where shale volume exceeded $18 \%$ for unconsolidated and $32 \%$ for calcite-rich sandstones, respectively (Fig. 11a). Here, DB occurrence is the number of times DB were seen in a given $\mathrm{V}_{\text {shale }}$ range and not the absolute number of deformation 


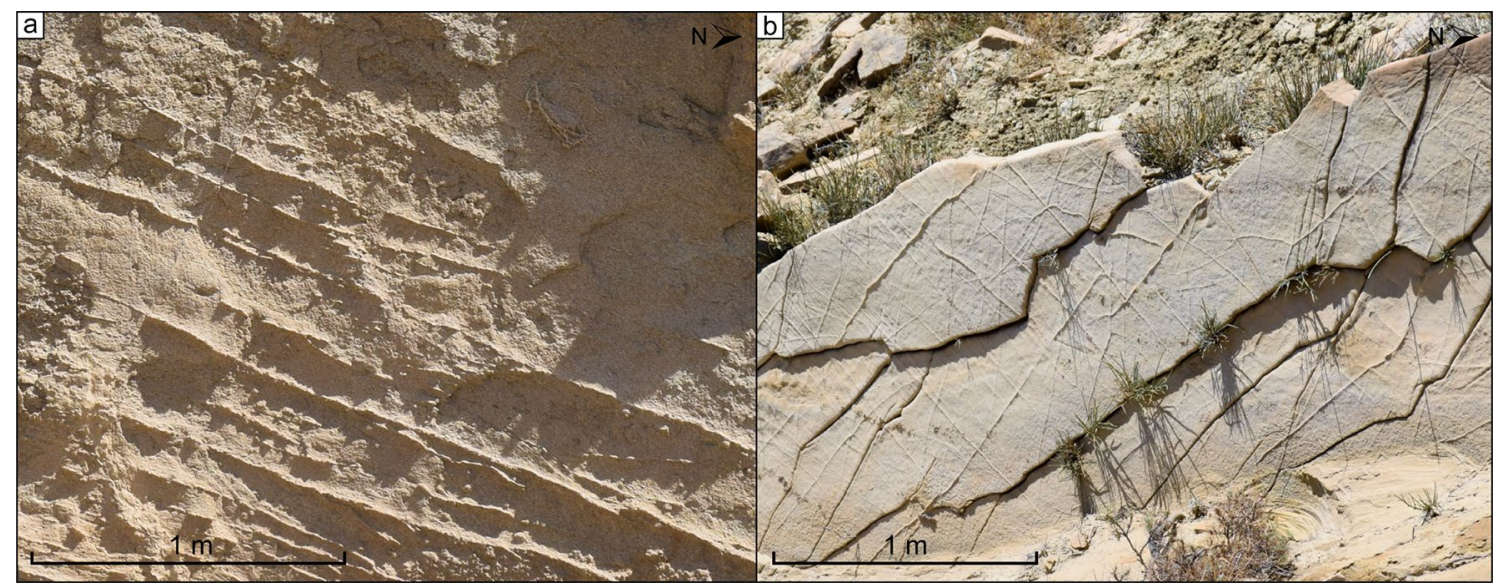

Fig. 9 Deformation bands (showing positive relief) and their distribution in unconsolidated (a) and calcite-rich (b) sandstones from Site 2 and Site 3, respectively. The view is to the outcrop face in the direction of true stratigraphic thickness. Site locations are shown in Fig. 2a

Fig. 10 Photomicrographs of cataclastic bands under parallel-(left column) and cross-polarized (right column) light for unconsolidated $(\mathbf{a}, \mathbf{b})$ and calcite-rich (c-f) sandstone samples. Deformation bands are dashed in yellow. Deformation band in $(\mathbf{a}, \mathbf{b})$ is composed of crushed quartz grains mixed with clays (Balakhany VII sample); band in (c, d) is a mixture of quartz, feldspar, and calcite (Balakhany VI sample); band in $(\mathbf{e}, \mathbf{f})$ is dominated by calcite (Balakhany VIII sample)

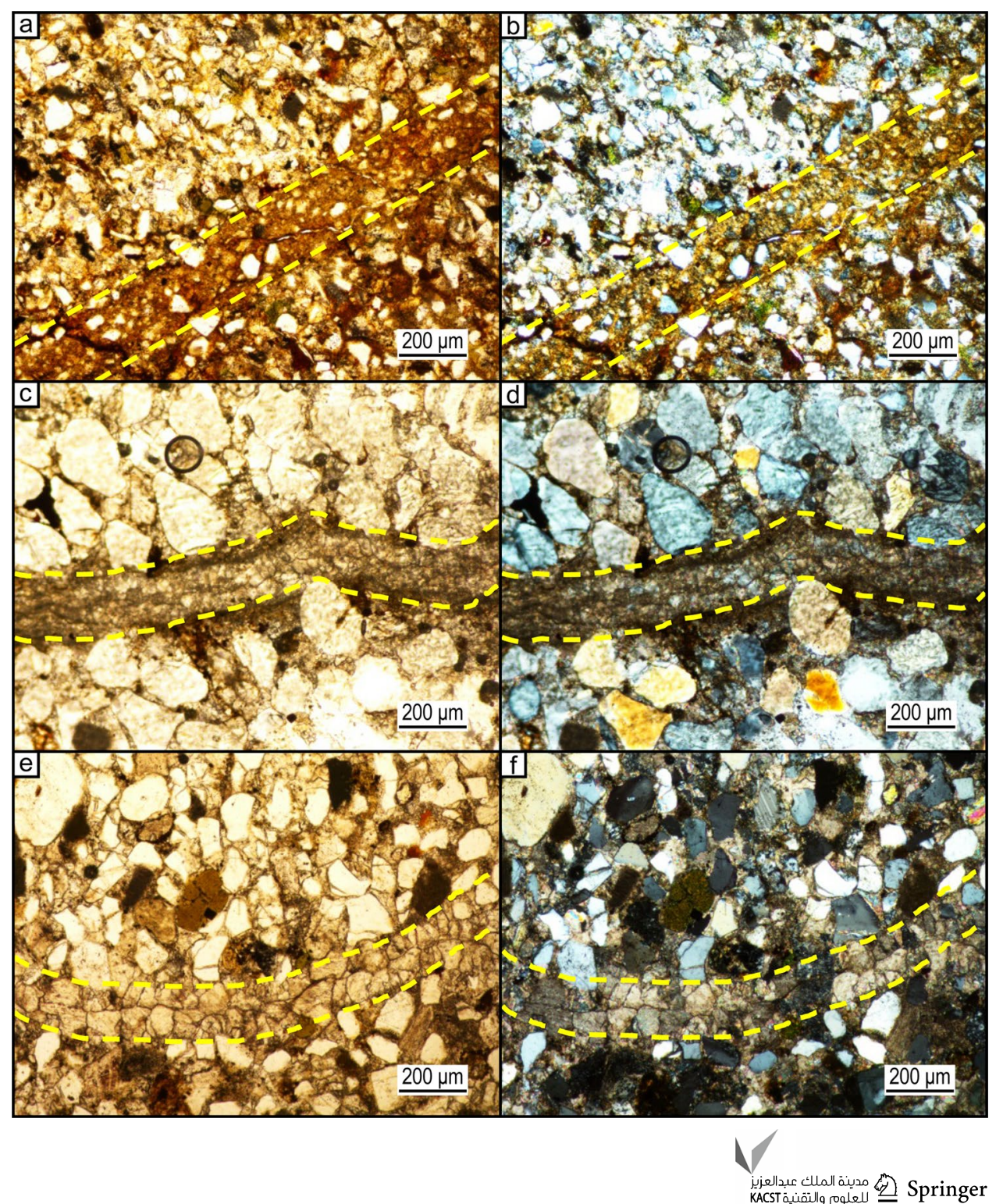


Table 1 Distribution of clay minerals in unconsolidated and calcite-rich sandstone layers (based on X-ray diffraction) with corresponding average concentration of deformation bands in the layer

\begin{tabular}{|c|c|c|c|c|c|}
\hline $\begin{array}{l}\text { Average \#DB/m } \\
\text { in the layer }\end{array}$ & Total clay $(\%)$ & $\begin{array}{l}\text { Montmoril- } \\
\text { lonite (\%) }\end{array}$ & Illite (\%) & Kaolinite (\%) & Sandstone facies \\
\hline 2 & 13.9 & 6.4 & 4 & 3.5 & Unconsolidated \\
\hline 2 & 16.6 & 7.5 & 4.4 & 4.7 & \\
\hline 7 & 9 & 6 & 3 & - & \\
\hline 7 & 7.4 & 4.3 & 3.1 & - & \\
\hline 0.65 & 8.5 & 4 & 2.5 & 2 & \\
\hline 2 & 8.8 & 4.1 & 2.7 & 2 & \\
\hline 2 & 5.5 & 3.5 & 2 & - & \\
\hline 2 & 6 & 4 & 2 & - & \\
\hline 0 & 21.3 & 10.7 & 5.2 & 5.4 & \\
\hline 0.26 & 7.5 & 5 & 2.5 & - & \\
\hline 0.26 & 2.6 & - & 2.6 & - & \\
\hline 0.15 & 5 & 3 & 2 & - & \\
\hline 0.15 & 5 & - & 2.5 & 2.5 & \\
\hline 10 & 4 & - & 2 & 2 & Calcite-rich \\
\hline 4 & 6.5 & 2 & 2.5 & 2 & \\
\hline 4 & 6.5 & 2 & 2.5 & 2 & \\
\hline 4 & 7 & 2 & 2.5 & 2.5 & \\
\hline 4 & 1.8 & - & 1.8 & - & \\
\hline 4 & 2 & - & 2 & - & \\
\hline 11 & 2 & - & 2 & - & \\
\hline 11 & 2 & - & 2 & - & \\
\hline 19 & 5 & - & 2.5 & 2.5 & \\
\hline 19 & 6 & - & 3 & 3 & \\
\hline 10 & 5 & - & 2.5 & 2.5 & \\
\hline 10 & 5 & - & 2.5 & 2.5 & \\
\hline 10 & 7 & - & 3.5 & 3.5 & \\
\hline 2 & 4 & - & 2 & 2 & \\
\hline 10 & 6 & - & 3 & 3 & \\
\hline 10 & 6 & - & 3 & 3 & \\
\hline
\end{tabular}

*Total clay is counted as the sum of illite, kaolinite, and montmorillonite fractions bands. The reduction in the occurrence of deformation bands correlates well with the increase in $V_{\text {shale }}$ in unconsolidated sandstones. Figure $11 \mathrm{~b}$ shows the probability of the occurrence of deformation bands based on the field measurements in Yasamal Valley, where the number of times DB were observed in the measured sections is divided by the total number of measurement points. The same trends are observed for both facies.

On the other hand, the absolute number of deformation bands, as mentioned earlier, depends on several confluence parameters, including the bed geometry. To further investigate the influence of clay content (in this case quantified through $V_{\text {shale }}$ ) on the absolute number of DB in the clean sandstones, the dip angle effect was diminished by selecting the batch of samples from individual unconsolidated and calcite-rich sandstone layers of the Balakhany VIII and VI subunits with a minor variation in dip angles (within the range of $\sim 2^{\circ}-3^{\circ}$ ). As shown in Fig. $11 \mathrm{c}$, the trends are certainly observed for both facies. Not only an overall increase in the concentration of deformation bands in the calcite-rich sandstone facies is observed, but also the shift in the $\mathrm{V}_{\text {shale }}$ threshold (from 18 to $32 \%$ ) for the presence or absence of deformation bands is confirmed as shown in Fig. 11a. In all of the cases described above, when these threshold values are met, the function of clay content in the formation of a deformation band becomes dominant over layer steepness, as shown in Fig. 11d where no DB were observed above the respective $\mathrm{V}_{\text {shale }}$ thresholds at any dip angle value.

From another perspective, the total clay content (comprised of illite, kaolinite, and montmorillonite fractions from XRD data shown in Table 1) of the Yasamal Valley sandstones was examined against the average number of deformation bands in the layer (Fig. 12). The sample taken from an unconsolidated silty sandstone layer where no deformation bands (or other deformation structures) were observed shows $21.3 \%$ clay content. Calcite-rich sandstone 

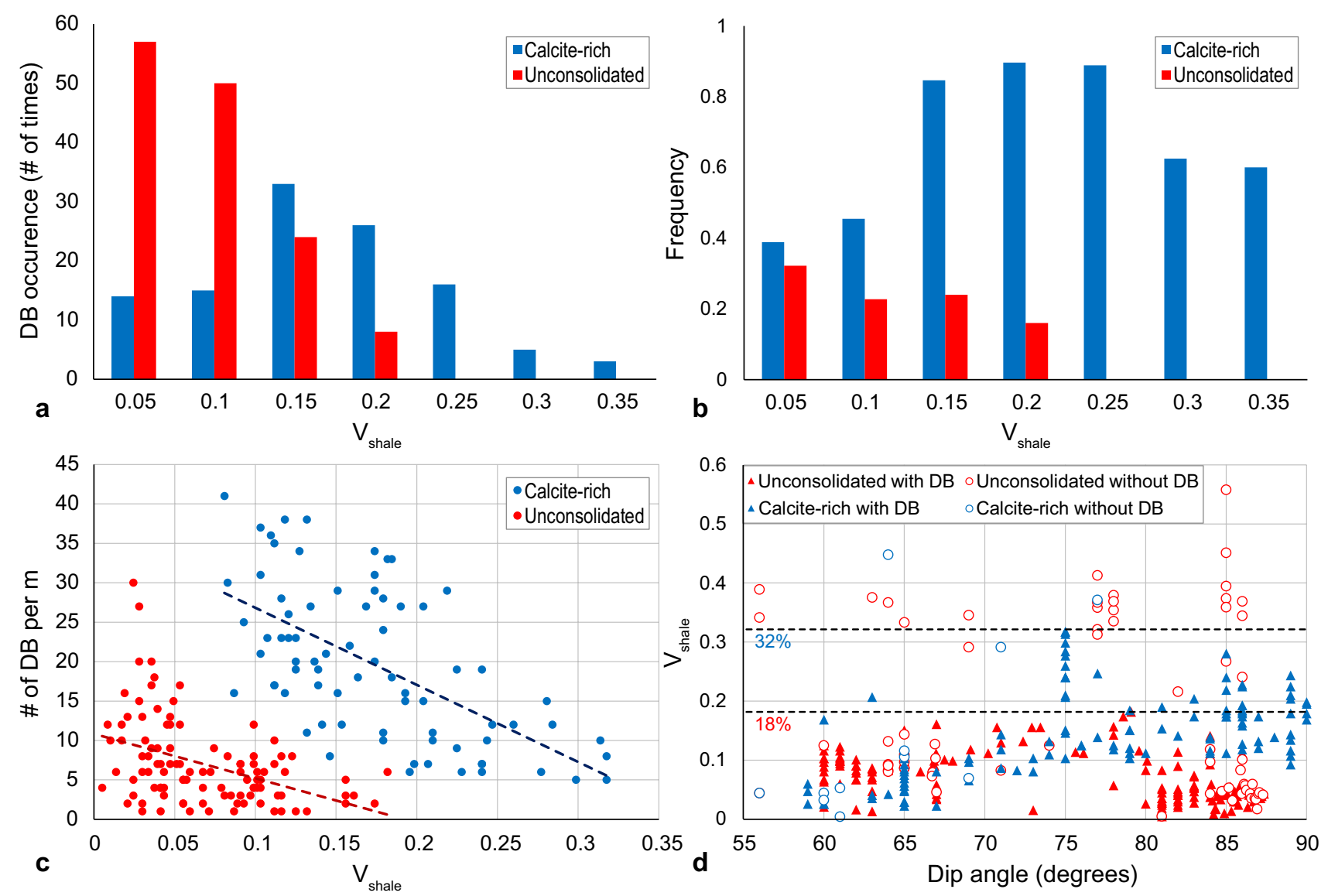

Fig. 11 Relationships of the occurrence (a), frequency (b), absolute number (c) of deformation bands (DB) with the shale volume derived from outcrop gamma-ray $\operatorname{logs}$ for unconsolidated and calcite-rich

sandstones at Yasamal Valley. d Range of bed dip angles for the given $V_{\text {shale }}$ values, showing data points with the presence and absence of DB

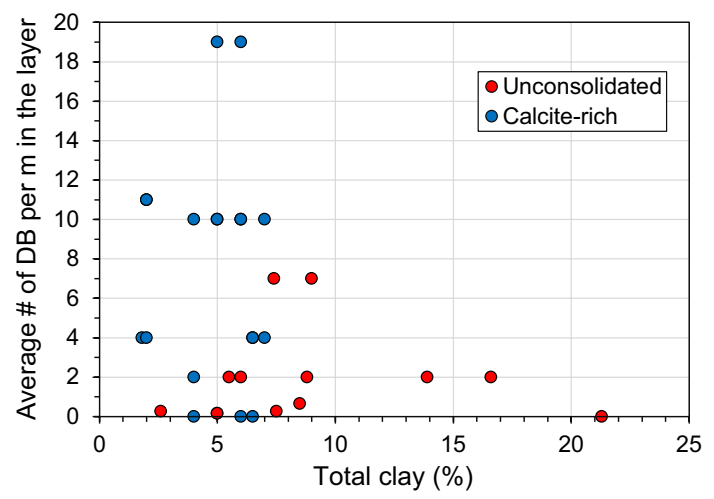

Fig. 12 Total clay content (sum of illite, kaolinite, and montmorillonite fractions from X-ray diffraction data) of sandstone layers plotted against the average number of deformation bands (DB) in the layer

layers show an overall higher band density compared to the unconsolidated units (Table 1 and Fig. 12), similar to the previous observations.

We also introduce another way of relating the lithology effect to the distribution of DB. During the graphical investigation of bands versus "sandwich net to gross" (see Eq. 1), no deformation bands were observed below a boundary netto-gross value of 0.31 (Fig. 13). This also applies when $V_{\text {shale }}$ is lower than the cutoff $18 \%$ (seen from the six blue points that lie below the net-to-gross threshold in Fig. 13), which shows that "sandwich net to gross" is another factor influencing the occurrence of DB in unconsolidated sandstones.

\section{Geometric/structural control}

The current-day structure of the Yasamal anticline suggests that the east limb has undergone relatively greater strain, as can be inferred from the steeply dipping $\left(60^{\circ}-90^{\circ}\right)$ and overturned layers (see Fig. 3). Numerous populations of DB were observed on the outcrops of this flank. In contrast, extensive observation of the gentler dipping (approximately $40^{\circ}$ ) rock exposures in the west flank of the anticline revealed no presence of deformation bands. This remarkable difference in

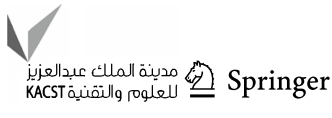




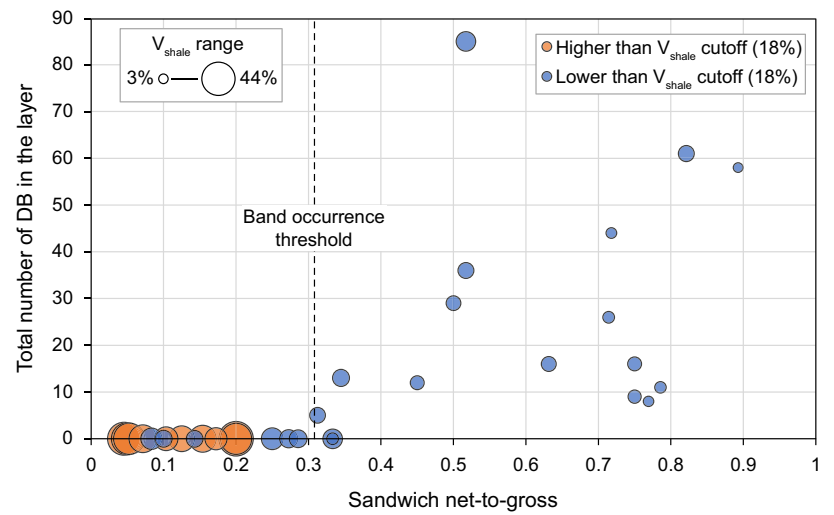

Fig. 13 Occurrence of deformation bands (DB) in unconsolidated sandstones versus "sandwich net to gross" of Balakhany subunits, showing the threshold value (0.31) below which no deformation bands are observed. Bubbles are sized by $V_{\text {shale }}$ and colored with respect to the $V_{\text {shale }}$ cutoff value (18\%)

the distribution of DB in the two limbs suggests that bed geometry is another influencing factor.

To quantify this influence, the absolute values for the dip angles of individual layers were used to correlate with the average number of deformation bands in those layers. Figure 14 shows that the relationship between the average concentration of DB and the dip angle in unconsolidated sandstones is less pronounced in the direction parallel to layering, compared to the data collected perpendicular to the bed plane. Although the values are scattered in both plots, in both cases, there is an increase in the concentration of DB with the steepness of the formations.

\section{Impact on reservoir properties}

The influence of deformation bands on the rock properties at the field scale is complicated due to the heterogeneous nature of the Balakhany Suite. To quantify this effect, the average permeability values of the unconsolidated sandstones layers were plotted against the average number of deformation bands in those beds, and an exponential trend in the reduction in permeability was observed (Fig. 15).

Compared to the field scale, the effect of deformation bands on the micro-scale porosity and permeability is more pronounced as the dimension of the band contained within a plug and that of the plug are comparable. Figure $16 \mathrm{com}$ pares the rock properties of the Balakhany VIII and VI sister plugs with and without a deformation band. As can be observed from the best-fit line equations, the permeability reduction is 33\% (Fig. 16a), while for porosity it amounts to $3 \%$ (Fig. 16b). The reducing effect of deformation bands can also be observed from the trendlines of porosity and permeability relationships in Fig. 16c, d.

The measured permeability values of the plugs with a single deformation band show reduction from one to three orders of magnitude compared to the host rock (Fig. 17). Calcite-rich sandstones have significantly lower permeability values both in the host rock $(0.18-11.6 \mathrm{mD}$ $\left.\left[1.91-123.23 \times 10-15 \mathrm{ft}^{2}\right]\right)$ and $\mathrm{DB}(0.002-0.12 \mathrm{mD}$ [0.021-1.28 $\left.\times 10-15 \mathrm{ft}^{2}\right]$ ) compared to unconsolidated sandstones but show similar orders of permeability reduction. It can also be observed that clay content does not correlate with the permeability contrast between the DB and the host rock.
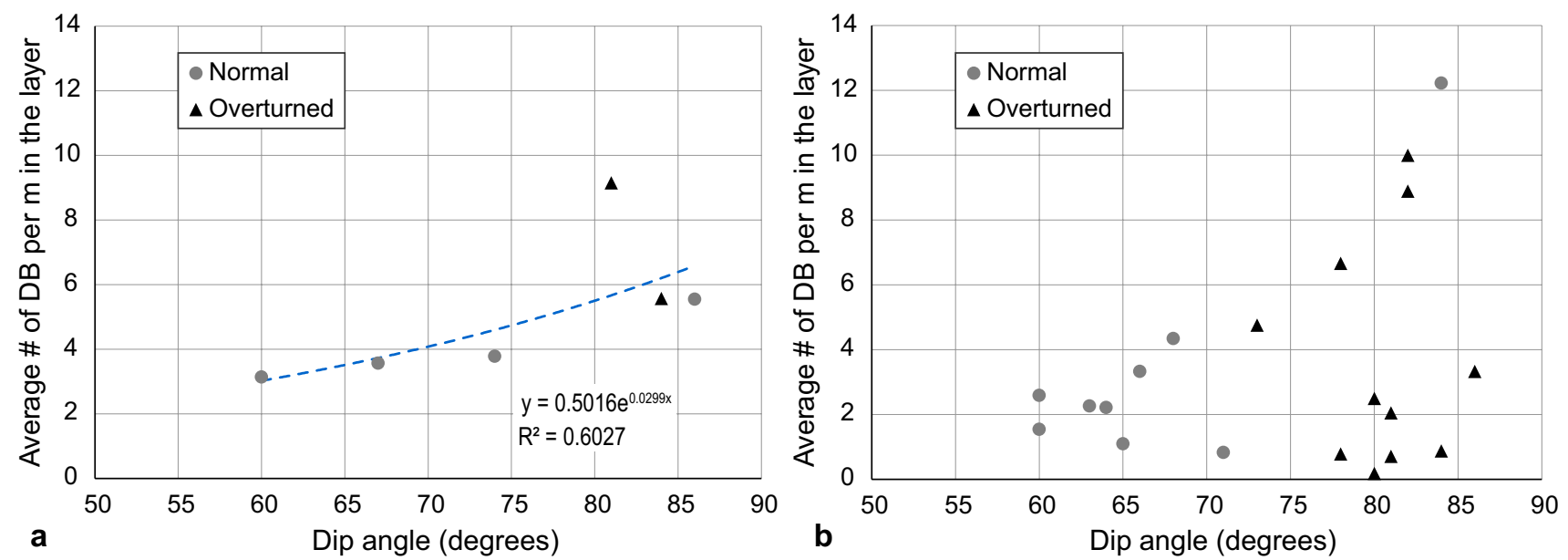

Fig. 14 Relationship between the average concentration of deformation bands (DB) in unconsolidated sandstone layers and the bed dip angle, measured parallel (a) and perpendicular (b) to layering 


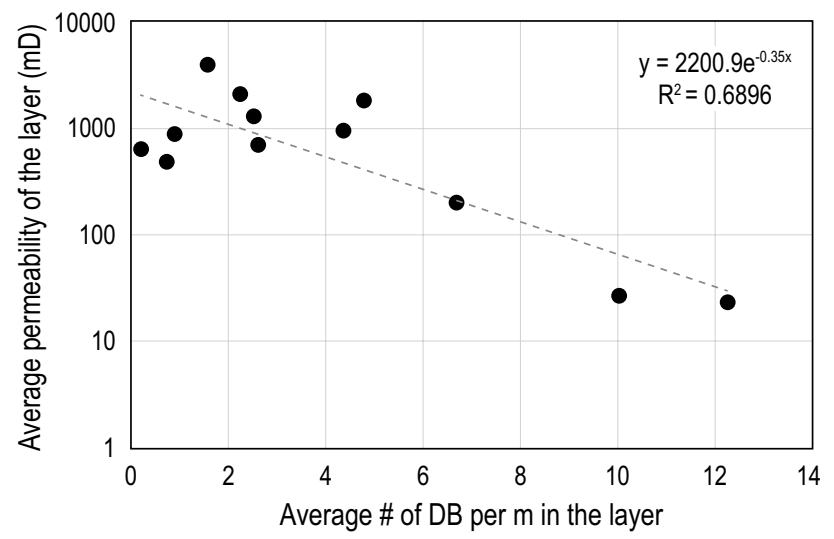

Fig. 15 Dependency of average permeability (TinyPerm II values converted to standard plug values) on the average concentration of deformation bands (DB) in the unconsolidated sandstone layers of Yasamal Valley
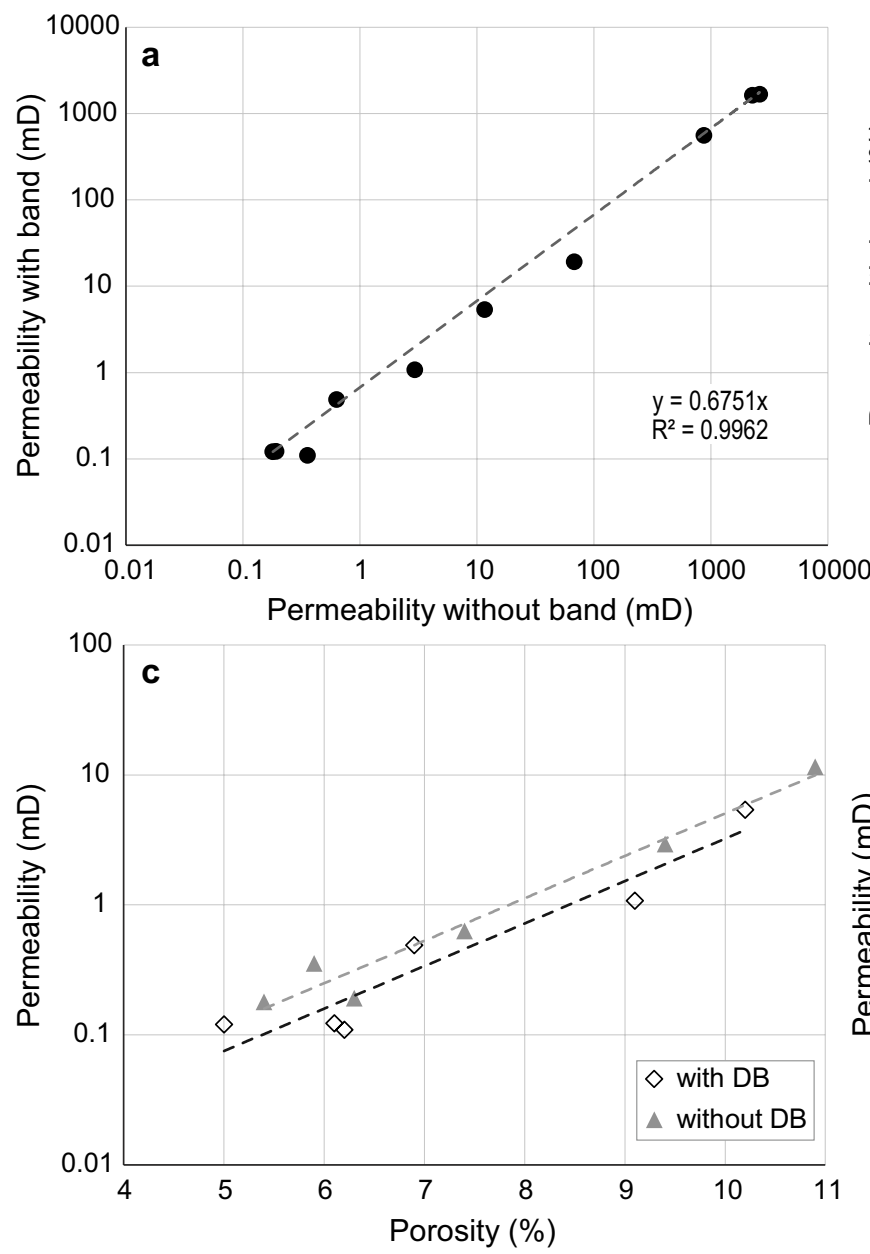

Fig. 16 Comparison of permeability (a) and porosity (b) values for sister plugs with and without a deformation band based on Routine Core Analysis. Best fit lines were set to derive the average reduction

\section{Discussions}

\section{Sandstone composition and $\boldsymbol{V}_{\text {shale }}$ approach}

To our knowledge, the $V_{\text {shale }}$ approach has not been implemented for quantification of formation conditions of deformation bands before. It is crucial to emphasize, again, that the $V_{\text {shale }}$ cutoff values (18\% for unconsolidated sandstones and $32 \%$ for calcite-rich sandstones) represent a centimeter-scale shale volume factor, which does not correspond directly to the clay content of the host rock, and are not to be compared to the results reported in other studies through quantification of clay content from micro-scale images of thin sections (e.g., cataclastic bands observed in poorly lithified sandstone with more than $30 \%$ clay and phyllosilicate content in Torabi 2014). Additionally, the application of other nonlinear methods of $V_{\text {shale }}$ calculation-such as the Larionov (1969) and Clavier (1971) equations that are known to estimate higher shale volume values than Steiber's
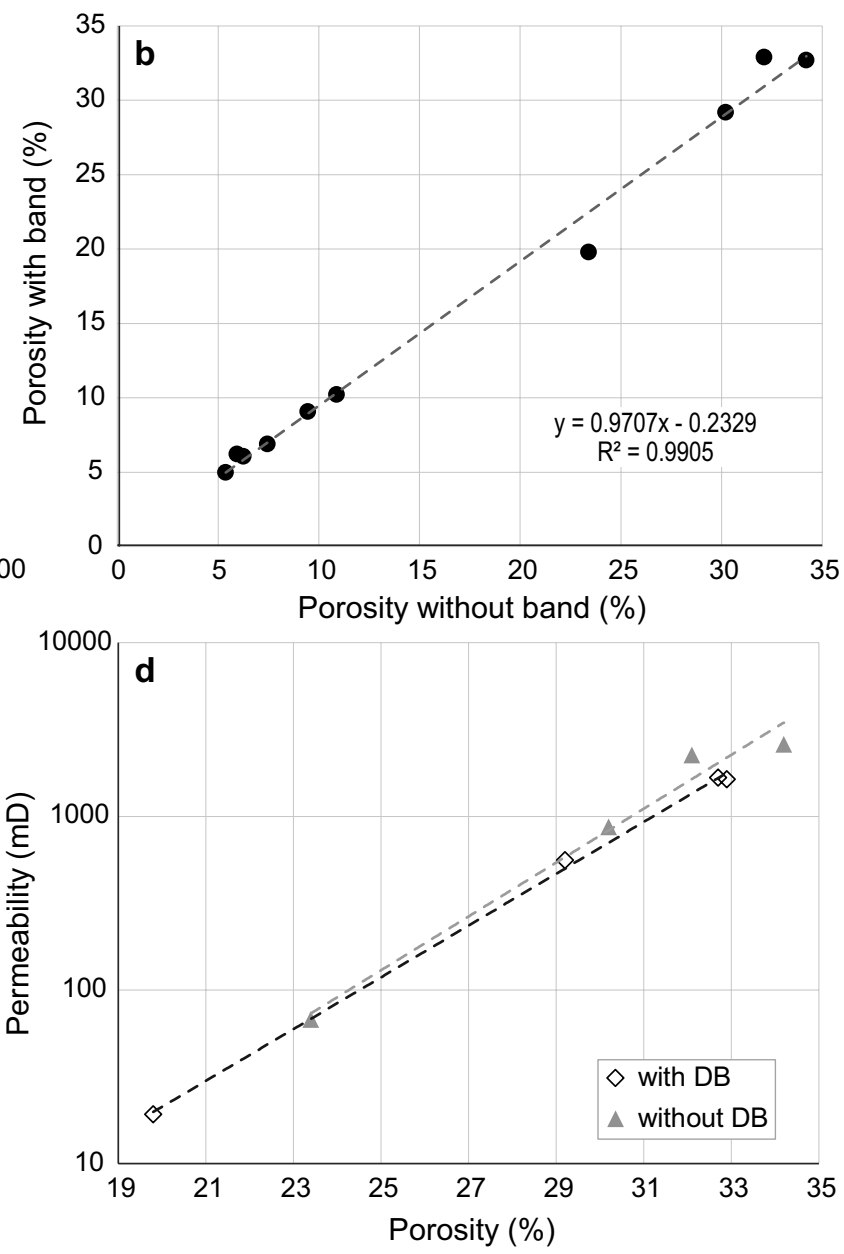

in properties. Refer to Table 2 for porosity and permeability measurements. Porosity vs permeability plots for calcite-rich (c) and unconsolidated (d) sandstones 
Table 2 Porosity and permeability data obtained from plugs (based on routine core analysis) with and without deformation bands (DB), and corresponding total clay content (based on X-ray diffraction)

\begin{tabular}{|c|c|c|c|c|c|c|}
\hline $\begin{array}{l}\text { Permeability of a } \\
\text { plug with } \mathrm{DB}(\mathrm{mD})\end{array}$ & $\begin{array}{l}\text { Permeability of a plug } \\
\text { without } \mathrm{DB}(\mathrm{mD})\end{array}$ & $\begin{array}{l}\text { Porosity of a } \\
\text { plug with DB }\end{array}$ & $\begin{array}{l}\text { Porosity of a } \\
\text { plug without DB }\end{array}$ & $\begin{array}{l}\text { Calculated permeability } \\
\text { of } \mathrm{DB} \text { in a plug }(\mathrm{mD})\end{array}$ & Total clay (\%) & Sandstone facies \\
\hline 19.23 & 67.84 & 19.8 & 23.4 & 1.42 & 15 & \multirow[t]{4}{*}{ Unconsolidated } \\
\hline 559.97 & 870.56 & 29.2 & 30.2 & 56.55 & 15.25 & \\
\hline 1671.88 & 2607.1 & 32.7 & 34.2 & 222.59 & 5 & \\
\hline 1636.63 & 2256.45 & 32.9 & 32.1 & 210.23 & N/A & \\
\hline 0.123 & 0.192 & 6.1 & 6.3 & 0.00442 & 6.5 & \multirow[t]{6}{*}{ Calcite-rich } \\
\hline 1.080 & 2.938 & 9.1 & 9.4 & 0.01828 & 6.5 & \\
\hline 0.490 & 0.633 & 6.9 & 7.4 & 0.02420 & N/A & \\
\hline 5.400 & 11.596 & 10.2 & 10.9 & 0.12165 & 1.9 & \\
\hline 0.110 & 0.356 & 6.2 & 5.9 & 0.00184 & 5.5 & \\
\hline 0.121 & 0.180 & 5.0 & 5.4 & 0.00384 & 5 & \\
\hline
\end{tabular}

*Permeability of a single deformation band was calculated using the harmonic average method (see text for details). Total clay is counted as the sum of illite, kaolinite, and montmorillonite fractions

1970 equation (Asquith and Krygowski 2004)—would yield different thresholds for DB formation. The $V_{\text {shale }} \log$ s in this study were acquired from three different locations of the anticline spanning $5 \mathrm{~km}$ (3.1 mi.) in length and encompassing 155-200 m (509-656 ft) of true stratigraphic thickness (or cumulative measured thickness of $375 \mathrm{~m}$ [1230 ft] from the three logs) (see Fig. 4b). This coverage is comparable to the scale of subsurface reservoirs, highlighting the value of the $\mathrm{V}_{\text {shale }}$ approach in predicting deformation bands.

The presence of the calcite cement in the pore space of the sandstone rocks indeed increases the number of DB, but also complicates their distribution pattern, seen from variously inclined and cross-cutting DB sets within the calciterich sandstone layers (see Fig. $9 \mathrm{~b}$ ). The increase in the $\mathrm{V}_{\text {shale }}$ threshold value for calcite-rich sandstones (compared to the calcite-poor, unconsolidated sandstones) is related to the brittleness of calcite cement in the pore space (Hoshino and Koide 1970). It has been observed that during deformation, microfractures form both in the calcite cement matrix and detrital (e.g., quartz) grains (Friedman 1963). Additionally, Xiao and Evans (2003) quantified that an increase in calcite amount decreases the bulk rock strength in synthetic calcite-quartz aggregates. The calcite content of the sandstones in our study is either low (10-20\% in unconsolidated sandstones) or very high (40-50\% in calcite-rich sandstones), which limits the analysis of the effect of calcite cement on DB concentration in the intermediate range.

Finally, while feldspar minerals are generally known to influence the occurrence of deformation bands and are also prone to fracturing and cataclasis (Exner and Tschegg 2012; Griffiths et al. 2018), such impact is not observed from the analysis of the studied samples, most likely due to the low amount of feldspar present in the rocks (10\% on average, refer to Fig. 7).

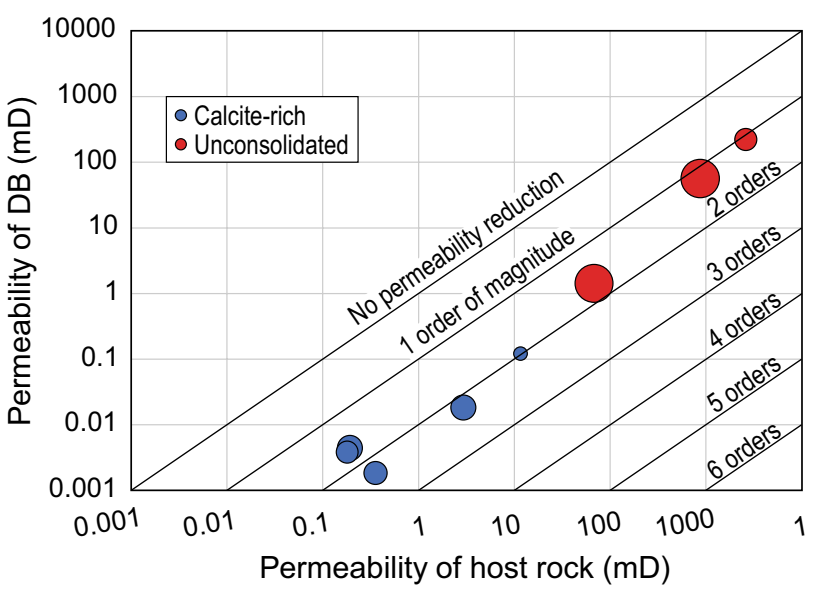

Fig. 17 Comparison of the estimated permeability (using harmonic average) of single deformation bands (DB) to the permeability of their host rocks, showing the magnitude of permeability reduction in the Yasamal Valley samples relative to the worldwide observations of zero to six orders of magnitude. Bubbles are sized by total clay minerals percentage derived from X-Ray Diffraction data and colored by sandstone facies

\section{"Sandwich net-to-gross" approach}

We believe that a contrast in the elastic properties of successive beds may cause a redistribution of stresses in individual sandstone units. Sandstones bound by thicker beds of mudstone might experience a decreased compressive load, potentially alleviating the generation of deformation bands. This heuristic led to our field-scale investigation to test if the intermediate to low net-to-gross succession of the Balakhany Suite affects the occurrence and concentration of deformation bands. This examination revealed another threshold for DB formation, which was not known a priori. To our knowledge, "sandwich net to gross" is a unique approach in analyzing the formation conditions of a deformation band, 
and its simplicity (Eq. 1) would allow this analysis to be applied directly to well logs. No previous experimental or modeling study was found on the effect of this parameter on the formation conditions of a deformation band. This and the $V_{\text {shale }}$ approach can be used as quick tools to make basic predictions about the presence (and concentration) or absence of deformation bands in analog subsurface fields.

\section{Structural geometry}

The wide presence of deformation bands in the steeply dipping east limb and their absence in the gentler dipping west limb of the Yasamal anticline suggest that the bed dip affects the occurrence of DB in the fold. Although a weak correlation, the concentration of deformation bands in Balakhany sandstones is higher in steeper beds. Zuluaga et al. (2014) and Fossen et al. (2017) observed similar, but clearer associations in the monoclinal limbs of fault-propagation folds (Navajo Sandstone in the San Rafael monocline and Entrada Sandstone in a monocline near the Colorado National Monument, respectively). Fossen et al. (2017) suggested that the variations in the relationship of the band number with dip largely depend on fold mechanism and lithological properties. We observe that the clay content of sandstones becomes a dominant factor in the formation of a deformation band when it reaches the reported, certain volumes, invariant of the bed dip (see Fig. 11c).

Apart from the dip angle, other structural elements can also influence the DB distribution. Souque et al. (2010) showed that grain crushing (fracturing) in the sandstone units depends on the structural position and increases from the limb to the hinge of the anticline in Yasamal Valley, related to relatively higher strain accommodation in the hinge zones. Similarly, Wilkins et al. (2020) observed a significantly higher density of deformation bands in reservoir sands near the hinge of the monocline in the Holstein Field, Gulf of Mexico, than in the downdip sands in its forelimb with similar petrological characteristics. The formation of DB in the hinge zones of fault-related folds was also observed in a few other studies, for example, the Youshashan anticline in the western Qaidam Basin, China (Liu and Sun 2020), and the Orange anticline in South East Basin, France (Soliva et al. 2013), both of which are faultpropagation folds. Abrupt changes in the dip angles along a short distance can lead to the occurrence of deformation bands and porosity collapse due to the dominating, kinematic shear component.

We, therefore, envisage an interdependence between the dip angle, dip change rate (i.e., curvature), and distance to the hinge zones with the concentration of deformation bands or porosity and/or permeability in the clean sandstone layers. In our study, the sampling rate of dip angle measurements was not sufficient for reliable dip gradient calculations because of the complications associated with on-site data acquisition (i.e., discontinuous exposures and inaccessible outcrops). Another challenge in the outcrop conditions of Yasamal Valley is to identify the distance of the data points to the highly eroded hinge zones, which would require reconstructing the structural evolution the plunging anticline. Although this may be a quick, practical solution to predict porosity and permeability reduction in the deformed areas of subsurface reservoir rocks (provided information on dip and dip azimuth from well logs, and hinge points from calibrated seismic surfaces are available), other factors can equally influence the occurrence and distribution of DB, such as the migration of hinges, stress history, and presence of faults (Farrell et al. 2014; Fossen et al. 2017; Torabi et al. 2021).

\section{Porosity and permeability}

Evidence of pervasive occurrence of DB within a fold can be a good indicator of regional deterioration of the rock properties. Our study suggests that the field-scale permeability decreases with an increasing number of DB. Since the relationship in Fig. 15 shows the average permeability of the individual layers (averaged from TinyPerm measurements in $30 \mathrm{~cm}[1 \mathrm{ft}]$ increment along those layers that included points both with and without DB), deformation bands appear to influence permeability away from the band plane, possibly caused by slight changes in the pore arrangement of the host rock adjacent to the band during deformation. Fossen et al. (2011) observed an opposite relationship between permeability and deformation band concentration when the permeability is higher than 10 darcy (converted to plug value). The authors claim that a higher host rock permeability suggests more "room" for the creation of deformation bands, given that there is a positive correlation between permeability and porosity. The contrast in these results might be caused by the significant difference in permeability values (the TinyPerm II measurements, converted to plug values, of unconsolidated sandstones in Yasamal Valley ranged from 246 to 4600 $\mathrm{mD}\left[2.61 \times 10^{-12} \mathrm{ft}^{2}\right.$ to $\left.4.89 \times 10^{-11} \mathrm{ft}^{2}\right]$, compared to values ranging between 10 and 50 darcy $\left[1.06-5.31 \times 10^{-10} \mathrm{ft}^{2}\right]$, converted to plug values from Figs. $9 \mathrm{~b}$ and 10 in Fossen et al. 2011) and grain sizes (Navajo sandstones are coarsegrained dune beds, while Balakhany sandstones are fine to very fine-grained [refer to Fig. 8]). The absence of coarsegrained sandstones in the Balakhany Suite does not allow us to perform sensitivity analysis with respect to the grain size variation.

At the pore scale, the existence of the impact of a deformation band on reservoir properties is more obvious, however, the degree of that impact varies for porosity and permeability. A deformation band has a higher influence on permeability in contrast to porosity (33\% vs. $3 \%$ 
reduction). Such a behavior is expected due to the nature of DB: the presence of small pore throats prevailing in a band (as observed from MICP-based pore size distributions in Gambino et al. 2019) creates a strong capillary pressure barrier within its proximity (Torabi et al. 2013), which has a stronger effect on the permeability, whereas the volume of the pores associated with the deformation band is very small; hence, there is less effect on the porosity of the plug. Quantifying the effect of various distribution patterns or amalgamation of deformation bands at larger scales (e.g., $3 \times 3 \times 3 \mathrm{~m}[10 \times 10 \times 10 \mathrm{ft}]$ sized sandstone chunk) is a challenging lab experiment and, to our knowledge, has not been done, yet. Romano et al. (2020) performed the first sub-core scale flow experiments, assisted by a micro-CT scanner, on a sample (5 cm [2 in.] in diameter and $10 \mathrm{~cm}$ [4 in.] in length) of Navajo Sandstone containing one cataclastic deformation band and two laminae. The results show that these laminae and DB act as a capillary barrier.

The magnitude of permeability reduction by a single deformation band documented in this study ( 1 to 3 orders of magnitude) has been widely observed in various sandstones mentioned by Ballas et al. (2015) and Fossen et al. (2017). These studies show that the order of reduction depends on deformation mechanism (e.g., degree of cataclasis, compaction, etc.) and several intrinsic properties of the host rock (e.g., mineralogical composition, grain size, sorting, etc.), which is probably the reason why an increase in clay content alone did not align well with an increase in the permeability contrast in Balakhany sandstones.

It should be noted that in the pervasively calcite-cemented sandstones, where porosity and permeability are reported to be substantially reduced (Dutton et al. 2000; Rahman and Worden 2016), the impact of deformation bands on fluid flow may become secondary and insignificant. This is observed in the calcite-rich sandstones (samples without DB) of Balakhany, which have poor reservoir quality regardless of deformation. Additionally, Del Sole and Antonellini (2019) showed that in the case of a pre-existing deformation, calcite cement precipitation enhances the porosity and permeability reduction effect caused by the deformation bands in sandstones. Our work did not include a study of the timing of DB formation with respect to the calcite precipitation.

\section{Conclusions}

We used field and laboratory measurements to quantitatively analyze the formation conditions of deformation bands, their distribution, and impact on porosity and permeability of sandstones at field and pore scales in a steeply dipping limb of an anticline fold. The results show that several factors control the occurrence and concentration of deformation bands, namely lithologic and mineralogic composition (shale volume, calcite cement), bed geometry (dip angle), and contrast in the elastic properties of successive beds (represented by sandstone net-to-gross thickness ratio). We present novel threshold values that can be used directly in analog fields to predict deformation bands.

Generally, the presence of deformation bands in the steeply dipping limb of Yasamal Valley reduces the average permeability of unconsolidated sandstone layers and is therefore an indicator of degraded reservoir quality. Laboratory results show that while porosity reduction between the outcrop samples with and without a deformation band (sister plugs) is around 3\%, for permeability this reduction is much greater, averaging at $33 \%$, and could potentially significantly baffle the fluid flow when upscaled to the reservoir production scale. The presence of excessive calcite cement $(>40 \%)$ in the sandstones significantly increases the number of deformation bands and complicates their distribution patterns, as well as significantly decreases the porosity and permeability; our data and previous literature suggest that calcite-cemented sandstones would therefore act as barriers to fluid flow.

The studied outcrops of the Balakhany Suite are equivalent in age, composition, and structural style to the Upper Productive Series reservoirs in the South Caspian Basin; therefore, the results of this study can be applied in geological modeling to predict reservoir properties and optimize well locations in the deformed sector of the offshore fields with degraded properties.

Acknowledgements The authors would like to thank the professionals from BP AGT Reservoir Development teams for their invaluable support during execution and various technical discussions throughout this study. We also express our deep gratitude to Azerbaijan International Operating Company (AIOC), all ACG partners, and SOCAR for funding this study and for the permission to publish.

Author contributions SA, GZ, AS involved in conceptualization; SA, GZ, AS took part in methodology; SA, AS, GZ involved in investigation; SA and AS took part in formal analysis; AS involved in visualization and writing-original draft; SA, AS, GZ involved in writing - review and editing; SA took part in data curation; GZ took part in validation; $\mathrm{SA}$ involved in funding acquisition; SA and GZ took part in project administration.

Funding This study was funded by Azerbaijan International Operating Company (AIOC).

\section{Declarations}

Conflict of interest The authors have no known competing financial or non-financial interests to disclose.

Open Access This article is licensed under a Creative Commons Attribution 4.0 International License, which permits use, sharing, adaptation, distribution and reproduction in any medium or format, as long as you give appropriate credit to the original author(s) and the source, provide a link to the Creative Commons licence, and indicate if changes 
were made. The images or other third party material in this article are included in the article's Creative Commons licence, unless indicated otherwise in a credit line to the material. If material is not included in the article's Creative Commons licence and your intended use is not permitted by statutory regulation or exceeds the permitted use, you will need to obtain permission directly from the copyright holder. To view a copy of this licence, visit http://creativecommons.org/licenses/by/4.0/.

\section{References}

Abdullayev NR, Weber J, van Baak CGC, Aliyeva E, Leslie C, Riley GW, O’Sullivan P, Kislitsiyn R (2018) Detrital zircon and apatite constraints on depositional ages, sedimentation rates and provenance: Pliocene Productive Series South Caspian, Basin, Azerbaijan. Basin Res 30:835-862

Ahmed T (2001) Reservoir engineering handbook. Gulf Professional Publishing, Houston

Aliyeva E (2005) Reservoirs of the lower pliocene productive series at the Western Flank of the South Caspian Basin. Lithol Min Resour 40:267-278

Alizadeh AA, Akhmedov GA, Akhmedov AM, Aliyev AK, Zeynalov MM (1966) Geology of oil and gas fields of Azerbaijan. Moscow, Nedra, p 283-288

Allen MB, Vincent SJ, Alsop GI, Ismail-zadeh A, Flecker R (2003) Late Cenozoic deformation in the South Caspian region: effects of a rigid basement block within a collision zone. Tectonophysics 366:223-239

Antonellini MA, Aydin A, Pollard DD (1994) Microstructure of deformation bands in porous sandstones at Arches National Park, Utah. J Struct Geol 16(7):941-959

Asquith G, Krygowski D (2004) Basic well log analysis: Tulsa. AAPG Methods Explor Ser 16:244

Atilla A, Ahmadov R (2009) Bed-parallel compaction bands in aeolian sandstone: their identification, characterization and implications. Tectonophysics 479:277-284

Awdal A, Suramairy R, Singh K, Fabre G, Alsop GI (2020) Deformation bands and their impact on fluid flow: insights from geometrical modelling and multi-scale flow simulations in sandstones. J Struct Geol 141:104215

Aydin A (1978) Small faults formed as deformation bands in sandstone. Pure Appl Geophys 116:913-930

Bai M (2016) Why are brittleness and fracability not equivalent in designing hydraulic fracturing in tight shale gas reservoirs. Petroleum 2:1-19

Ballas G, Fossen H, Soliva R (2015) Factors controlling permeability of cataclastic deformation bands and faults in porous sandstone reservoirs. J Struct Geol 76:1-21

Beke B, Fodor L, Millar L, Petrik A (2019) Deformation band formation as a function of progressive burial: depth calibration and mechanism change in the Pannonian Basin (Hungary). Mar Petrol Geol 105:1-16

Botter C, Cardozo N, Lecomte I, Rotevatn A, Paton G (2016) The impact of faults and fluid flow on seismic images of a relay ramp over production time. Pet Geosci 23:17-28

Brunet MF, Korotaev M, Ershov A, Nikishin AM (2003) The South Caspian basin: a review of its evolution from subsidence modeling. In: Brunet MF, Cloetingh S (eds) Integrated Peri-Tethyan Basins Studies (Peri-Tethys Programme). Sedimentary Geology, vol 156, pp 119-148

Das A, Nguyen GD, Einav I (2011) Compaction bands due to grain crushing in porous rocks: a theoretical approach based on breakage mechanics. J Geophys Res 116:B08203
Das A, Nguyen GD, Einav I (2013) The propagation of compaction bands in porous rocks based on breakage mechanics. J Geophys Res 118:2049-2066

Del Sole L, Antonellini M (2019) Microstructural, petrophysical, and mechanical properties of compactive shear bands associated to calcite cement concretions in arkose sandstone. J Struct Geol 126:51-68

Devlin WJ, Cogswell JM, Gaskins GM, Isaksen GH, Pitcher DM, Puls DP, Stanley KO (1999) South caspian Basin: young, cool, and full of promise. GSA Today $9(7): 1-9$

Dutton SP, Willis BJ, White CD, Bhattacharya JP (2000) Outcrop characterization of reservoir quality and interwell-scale cement distribution in a tide-influenced delta, frontier formation, Wyoming, USA. Clay Miner 35:95-105

Elphick KE, Lv A, Roshan H, Sloss CR, Regenauer-Lieb K, Schrank CE (2021) Regular spacing of deformation bands in sandstone: Layer-thickness control or constitutive instability? J Struct Geol 147:104335

Exner U, Tschegg C (2012) Preferential cataclastic grain size reduction of feldspar in deformation bands in poorly consolidated arkosic sands. J Struct Geol 43:63-72

Farrell NJC, Healy D, Taylor CW (2014) Anisotropy of permeability in faulted porous sandstones. J Struct Geol 63:50-67

Fossen H, Bale A (2007) Deformation bands and their influence on fluid flow. AAPG Bull 91:1685-1700

Fossen H, Shultz RA, Shipton ZK, Mair K (2007) Deformation bands in sandstone: a review. J Geol Soc 164:755-769

Fossen H, Schultz RA, Torabi A (2011) Conditions and implications for compaction band formation in the Navajo Sandstone, Utah. J Struct Geol 33:1477-1490

Fossen H, Soliva R, Ballas G, Trzaskos B, Cavalcante C, Schultz RA (2017) A review of deformation bands in reservoir sandstones: geometries, mechanisms and distribution: geological Society. Special Publications, London, p 459

Friedman M (1963) Petrofabric analysis of experimentally deformed calcite-cemented sandstones. J Geol 71:12-37

Gambino S, Fazio E, Maniscalco R, Punturo R, Lanzafame G, Barreca G, Butler RWH (2019) Fold-related deformation bands in a weakly buried sandstone reservoir analogue: a multi-disciplinary case study from the Numidian (Miocene) of Sicily (Italy). J Struct Geol 118:150-164

Granath JW, Baganz OW (1996) A review of Neogene subsidence mechanisms for the South Caspian basin. In: 3rd Annual meeting and fieldtrip of IGCP project nj369 " comparative evolution of Peri-Tethyan rift basins", pp 24-25

Green T, Abdullayev N, Hossack J, Riley G, Roberts AM (2009) Sedimentation and subsidence in the South Caspian Basin, Azerbaijan. Geol Soc Lond Spec Publ 312:241-260

Griffiths J, Faulkner DR, Edwards AP, Worden RH (2018) Deformation band development as a function of intrinsic host-rock properties in Triassic Sherwood Sandstone. Geol Soc (Lond) Spec Publ, 435, 161-176.

Gurevich AE, Chilingar G (1995) Abnormal pressures in Azerbaijan: a brief critical review and recommendations. J Petrol Sci Eng 13:125-135

Hinds DJ, Aliyeva E, Allen MB, Davies CE, Kroonenberg SB, Simmons MD, Vincent SJ (2004) Sedimentation in a discharge dominated fluvial-lacustrine system: the Neogene Productive Series of the South Caspian Basin, Azerbaijan. Mar Petrol Geolo 21:613-638

Hoshino K, Koide H (1970) Process of deformation of the sedimentary rocks. In: Proceedings of the 2 nd congress of the international society for rock mechanics, vol 2-13, pp 353-359

Jackson J, Priestley K, Allen M, Berberian M (2002) Active tectonics of the South Caspian Basin. Geophys J Int 148:214-245

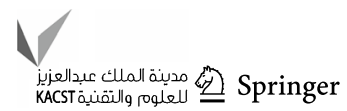


Jones RW, Simmons MD (1996) A review of the stratigraphy of Eastern Paratethys (Oligocene-Holocene). Bull Nat Hist Museum Lond (geol Suppl) 52:25-49

Keehm Y, Sternlof K, Mukerji T (2006) Computational estimation of compaction band permeability in sandstone. Geosci J 10:499-505

Knipe RJ, Fisher QJ, Clennell MR, Farmer AB, Harrison A, Kidd B, McAllister E, Porter JR, White EA (1997) Fault seal analysis: successful methodologies, application and future directions. In Møller-Pedersen P, Koestler AG (eds) Hydrocarbon seals: importance for exploration and production: Norwegian Petroleum Society Special Publication 7, pp 15-40

Kroonenberg SB, Alekseevski NI, Aliyeva E, Allen MB, Aybulatov DN, Baba-Zadeh A, Badyukova EN, Davies CE, Hinds DJ, Hoogendoorn RM, Huseynov D, Ibrahimov B, Mamedov P, Overeem I, Rusakov GV, Suleymanova S, Svitoch AA, Vincent SJ (2005) Two deltas, two basins, one river, one sea: the modern Volga delta as an analogue of the Neogene Productive Series, South Caspian Basin. In: Giosan L, Bhattacharya JP (eds) River deltas-concepts, models and examples. SEPM Special Publication 83, Broken Arrow, OK, pp 231-256

Liu Z, Sun Y (2020) Characteristics and formation process of contractional deformation bands in oil-bearing sandstones in the hinge of a fold: a case study of the Youshashan anticline, western Qaidam Basin, China. J Pet Sci Eng 189:106994

Liu Z, Fu X, Deng S, Meng L, Wang H, Sun Y, Chen Z (2021) The critical control of arkosic sandstone porosity on deformation band formation: Insights from the Shulu across-fault borehole in the Bohai Bay Basin, China. J Struct Geol 143:104258

Matthai SK, Aydin A, Pollard DD, Roberts SG (1998) Numerical simulation of departures from radial drawdown in a faulted sandstone reservoir with joints and deformation bands. Geol Soc Lond Spec Publ 147:157-191

Nemcok M, Feyzullayev AA, Kadirov FA, Zeynalov GA, Allen R, Christensen C, Welker B (2011) Neotectonics of the Caucasus and Kura Valley, Azerbaijan. Glob Eng Technol Rev 1:1-14

Nogueira FCC, Nicchio MA, Balsamo F, Souza JAB, Silva IVL, Bezerra FHR, Vasconcelos DL, Carvalho BRBM (2021) The influence of the cataclastic matrix on the petrophysical properties of deformation bands in arkosic sandstones. Mar Petrol Geol 124:104825

Pourmalek A, Newell AJ, Shariatipour SM, Butcher AS, Milodowski AE, Bagheri M, Wood AM (2021) Deformation bands in highporosity sandstones: Do they help or hinder $\mathrm{CO} 2$ migration and storage in geological formations? Int J Greenhouse Gas Control 107:103292

Rahman MJJ, Worden RH (2016) Diagenesis and its impact on the reservoir quality of Miocene sandstones (Surma Group) from the Bengal Basin, Bangladesh. Mar Petrol Geol 77:898-915

Reynolds AD, Simmons MD, Bowman MBJ, Henton J, Brayshaw AC, Ali-Zade AA, Guliyev IS, Suleymanova SF, Ateava EZ, Mamedova DN, Koshkarly RO (1998) Implication of outcrop geology for reservoirs in the Neogene Apsheron Peninsula, Azerbaijan. AAPG Bull 82:25-49

Robert R, Souloumiac P, Robion P, David C (2019) Numerical simulation of deformation band occurrence and the associated stress field during the growth of a fault-propagation fold. Geosciences (switzerland) 9:1-17. https://doi.org/10.3390/geosciences9060257

Romano CR, Zahasky C, Garing C, Minto JM, Benson SM, Shipton ZK, Lunn RJ (2020) Subcore scale fluid flow behavior in a sandstone with cataclastic deformation bands. Water Resour Res 56:1-16. https://doi.org/10.1029/2019WR026715

Romano CR, Garing C, Minto JM, Benson SM, Shipton ZK, Lunn RJ (2021) Extreme capillary heterogeneities and in situ fluid compartmentalization due to clusters of deformation bands in sandstones. Int J Greenhouse Gas Control 106:103280
Rotevatn A, Tveranger J, Howell JA, Fossen H (2009) Dynamic investigation of the effect of a relay ramp on simulated fluid flow: geocellular modelling of the Delicate Arch Ramp, Utah. Petrol Geosci $15: 45-58$

Rotevatn A, Fossmark HS, Bastesen E, Thorsheim E, Torabi A (2016) Do deformation bands matter for flow? Insights from permeability measurements and flow simulations in porous carbonate rocks. Pet Geosci 23:104-119

Sanderson DJ (2016) Field-based structural studies as analogues to sub-surface reservoirs. Geol Soc Spec Pub 436:207-217

Shipton ZK, Cowie PA (2001) Damage zone and slip-surface evolution over $\mu \mathrm{m}$ to $\mathrm{km}$ scales in high-porosity Navajo sandstone, Utah. J Struct Geol 23(12):1825-1844

Silva de Souza DH, Nogueira FCC, Vasconcelos DL, Torabi A, Braz de Souza JA, Nicchio MA, Pérez YAR, Balsamo F (2021) Growth of cataclastic bands into a fault zone: a multiscalar process by microcrack coalescence in sandstones of Rio do Peixe Basin, NE Brazil. J Struct Geol 146:104315

Soliva R, Schultz RA, Ballas G, Taboada A, Wibberley C, Saillet E, Benedicto A (2013) A model of strain localization in porous sandstone as a function of tectonic setting, burial and material properties; new insight from Provence (southern France). J Struct Geol 49:50-63

Soliva R, Ballas G, Fossen H, Philit S (2016) Tectonic regime controls clustering of deformation bands in porous sandstone. $\mathrm{J}$ Geol 44:423-426

Souque C, Fisher QJ, Casey M, Bentham P (2010) Structural controls on mechanical compaction within sandstones: an example from the Apsheron Peninsula Azerbaijan. Mar Petrol Geol 27:1713-1724

Sternlof KR, Karimi-Fard M, Pollard DD, Durlofsky LJ (2006) Flow and transport effects of compaction bands in sandstone at scales relevant to aquifer and reservoir management. Water Resour Res 42:W07425

Tembe S, Baud P, Wong T (2008) Stress conditions for the propagation of discrete compaction bands in porous sandstone. J Geophys Res 113:B09409

Torabi A (2014) Cataclastic bands in immature and poorly lithified sandstone, examples from Corsica, France. Tectonophysics 630:91-102

Torabi A, Fossen H (2009) Spatial variation of microstructure and petrophysical properties along deformation bands in reservoir sandstones. AAPG Bull 93(7):919-938

Torabi A, Fossen H, Alaei B (2008) Application of spatial correlation functions in permeability estimation of deformation bands in porous rocks. J Geophys Res 113:B08208

Torabi A, Fossen H, Alvar B (2013) Insight into petrophysical properties of deformed sandstone reservoirs. AAPG Bull 97:619-637

Torabi A, Balsamo F, Nogueira FCC, Vasconcelos DL, Silva ACE, Bezerra FHR, Souza JAB (2021) Mar Petrol Geol 133:105297

Tsang C, Neretnieks I (1998) Flow channeling in heterogeneous fractured rocks. Rev Geophys 36:275-298

Wentworth CK (1922) A scale of grade and class terms for clastic sediments. J Geol 30:377-392

Wilkins SJ, Davies RK, Naruk SJ (2020) Subsurface observations of deformation bands and their impact on hydrocarbon production within the Holstein Field, Gulf of Mexico, USA. In: Ogilvie SR, Dee SJ, Wilson RW, Bailey WR (eds) Integrated Fault Seal Analysis. Geological Society of London Special Publications 496, London, UK, pp 223-252

Wilson Penelope IR, Wilson RW, Sanderson DJ, Jarvis I, McCaffrey KJW (2021) Analysis of deformation bands associated with the Trachyte Mesa intrusion, Henry Mountains, Utah: implications for reservoir connectivity and fluid flow around sill intrusions. Solid Earth 12:95-117 
Wu H, Zhao J, Liang W (2020) The signature of deformation bands in porous sandstones. Rock Mech Rock Eng. https://doi.org/10. 1007/s00603-020-02100-8

Xiao X, Evans B (2003) Shear-enhanced compaction during non-linear viscous creep of porous calcite-quartz aggregates. Earth Planet Sci Lett 216:725-740

Xiong L, Wu S, Wu T (2021) Effect of grain sorting, mineralogy and cementation attributes on the localized deformation in porous rocks: a numerical study. Tectonophysics 817:229041

Zhou X, Karimi-Fard M, Durlofsky LJ, Atilla A (2014) Fluid flow through porous sandstone with overprinting and intersecting geological structures of various types: Advances in the study of fractured reservoirs. Geol Soc (Lond) Spec Publ 374:101-111

Zonenshain LP, Pichon X (1986) Deep basins of the Black Sea and Caspian Sea as remnants of Mesozoic back-arc basins. Tectonophysics 123:181-211
Zuluaga LF, Fossen H, Rotevatn A (2014) Progressive evolution of deformation band populations during Laramide fault-propagation folding: Navajo Sandstone San Rafael monocline, Utah, USA. J Struct Geol 68:66-81

Zuluaga LF, Rotevatn A, Keilegavlen E, Fossen F (2016) The effect of deformation bands on simulated fluid flow within fault-propagation fold trap types: lessons from the San Rafael monocline Utah. AAPG Bull 100:1523-1540

Publisher's Note Springer Nature remains neutral with regard to jurisdictional claims in published maps and institutional affiliations. 